\title{
Nitrogen fixation in the Southern Ocean: a case of study of the Fe-fertilized Kerguelen region (KEOPS II cruise)
}

\author{
M. L. González ${ }^{1}$, V. Molina ${ }^{2}$, L. Florez-Leiva ${ }^{3}$, L. Oriol ${ }^{4}$, A. J. Cavagna ${ }^{5}$, \\ F. Dehairs ${ }^{5}$, L. Farias ${ }^{6}$, and C. Fernandez ${ }^{4,7,8}$ \\ ${ }^{1}$ Graduate Program in Oceanography, Department of Oceanography, University of \\ Concepcion, Concepción, Chile \\ ${ }^{2}$ Faculty of Natural Science, University of Playa Ancha, Valparaíso, Chile \\ ${ }^{3}$ Biology Program, University of Magdalena, Santa Marta, and Oceanography Program, \\ University of Antioquia, Medellin, Colombia \\ ${ }^{4}$ Sorbonne Universités, UPMC Univ Paris 06, UMR 7621, Laboratoire d'Océanographie \\ Microbienne, Observatoire Océanologique, 66650 Banyuls/mer, France \\ ${ }^{5}$ Analytical, Environmental and Geo-Chemistry, Earth System Sciences research group, Vrije \\ Universiteit Brussel, Belgium \\ ${ }^{6}$ Laboratory of Oceanographic and Climate Processes (PROFC), Department of \\ Oceanography, University of Concepción, and Center for Climate Change and Resilience \\ Research (CR2), Concepción, Chile \\ ${ }^{7}$ CNRS, UMR 7621, Laboratoire d'Océanographie Microbienne, Observatoire Océanologique, \\ 66650 Banyuls/mer, France
}

Nitrogen fixation in the Southern Ocean

M. L. González et al.

Title Page

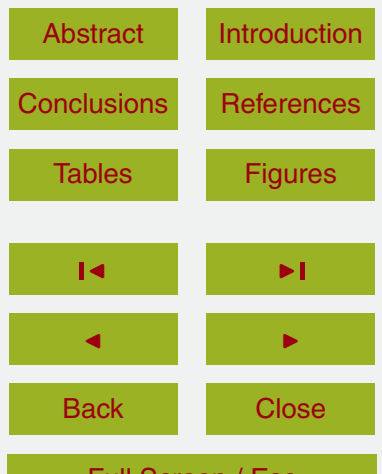

Full Screen / Esc

Printer-friendly Version

Interactive Discussion 
${ }^{8}$ Department of Oceanography, COPAS SurAustral program and Interdisciplinary center for Aquaculture Research (INCAR), University of Concepción, Chile

Received: 17 November 2014 - Accepted: 19 November 2014 - Published: 10 December 2014

Correspondence to: M. L. González (magonzalez@udec.cl)

Published by Copernicus Publications on behalf of the European Geosciences Union.

Printer-friendly Version

Interactive Discussion

(c) (1) 


\section{Abstract}

$\mathrm{N}_{2}$ fixation rates were measured during the KEOPS2 cruise in the HNLC area of Southern Ocean and in naturally iron-fertilized waters (Kerguelen Island $49.25^{\circ} \mathrm{S}, 69.58^{\circ} \mathrm{E}$ ) using the ${ }^{15} \mathrm{~N}$ isotopic technique. We detected $\mathrm{N}_{2}$ fixation within the mixed layer at all 5 stations, from the surface to $140 \mathrm{~m}$ depth. The data shows high variability with rates ranging between 0.42 and $20.11 \mathrm{nmol} \mathrm{NL}^{-1} \mathrm{~d}^{-1}$. The highest rates were concentrated in the euphotic layer and maximum values were obtained north of polar front (station $\mathrm{F}-\mathrm{L})$, which coincide with a positive $\mathrm{N}^{*}\left(\left[\mathrm{NO}_{3}\right]-16\left[\mathrm{PO}_{4}\right]\right)$, high chlorophyll concentration and dissolved iron. $\mathrm{N}_{2}$ fixation rates were also obtained in stations with moderate (A3-2; $10 \mathrm{E}-4 \mathrm{~W})$ and also low (R-2) iron levels as well as $\mathrm{Chl}$ a, suggesting that beside the microbial biomass, its composition/structure is a driving factor controlling $\mathrm{N}_{2}$ fixation activities. Molecular analysis showed a diazotrophic community dominated by heterotrophic bacterioplankton. Size fractioned experiments indicated that most of $\mathrm{N}_{2}$ fixating activities came from $<5 \mu \mathrm{m}$ community and it was on line with molecular analysis revealing 15 a low diversity diazotrophic community dominated by heterotrophic bacterioplankton. This study shows for first time $\mathrm{N}_{2}$ fixation is occurring in the Southern Ocean, at rates exceeding previous reports for high latitudes. Our findings suggest an indirect role of $\mathrm{dFe}$ in the regulation of $\mathrm{N}_{2}$ fixation through the enhancement of regenerated primary production and the availability of phytoplankton-derived dissolved organic matter, which in turn may stimulate heterotrophic bacterioplankton.

\section{Introduction}

Molecular nitrogen $\left(\mathrm{N}_{2}\right)$ fixation, carried out by diazotrophs, adds nitrogen to the ocean and effectively contributes to the input of new $\mathrm{N}$ for new primary production (Falkowski, 1997) and exported production (Gruber and Sarmiento, 1997). Although it has been suggested that $\mathrm{N}_{2}$ fixation could balance $\mathrm{N}$ losses derived from anaerobic processes such as denitrification (Codispoti, 1995) and anammox (Dalsgaard et al., 2003) at the
BGD

$11,17151-17185,2014$

Nitrogen fixation in the Southern Ocean

M. L. González et al.

Title Page



Full Screen / Esc

Printer-friendly Version

Interactive Discussion 
scale of ocean circulation (1000 years), the $\mathrm{N}$ cycle in the current ocean seems to be out of balance. Part of the uncertainty precluding a better estimation of $\mathrm{N}$ inputs and outputs comes from early assumptions of $\mathrm{N}_{2}$ fixation only occurring in chronically oligotrophic conditions.

5 It is currently accepted that $\mathrm{N}_{2}$ fixation is not limited to photosynthetic organisms such as Trichodesmiun sp. (Capone et al., 2005) and other diazotrophic coccoid cyanobacteria (Zehr et al., 1998; Montoya et al., 2004). Molecular tools have allowed observing diazotrophic activity in unicellular cyanobacteria as well as non-photosynthetic bacterioplankton (Church et al., 2005; Falcón et al., 2004; Moisander et al., 2008; Riemann 10 et al., 2010; Zehr et al., 2008, 1998, 2001). The genes for $\mathrm{N}_{2}$ fixation have been observed in many aquatic habitats, even when biogeochemical assays have failed to detect $\mathrm{N}_{2}$ fixation (Moisander et al., 2006). Although the abundance of $\mathrm{N}_{2}$-fixing bacteria is relatively low compared to non $\mathrm{N}_{2}$-fixing populations (Zehr and Kudela, 2011), the diversity of diazotrophs is increasingly important and it currently includes groups 15 within alpha and gamma-proteobacteria and archaea (Loescher et al., 2014; Mehta and Baross, 2006; Short et al., 2004).

There is a variety of strategies for diazotrophic communities to cope with oxygen (nitrogen fixation is an anaerobic process) as well as nutrient limitation. Specialized structures such as heterocysts in Anabaena and diazocyst in Trichodesmiun (Bergman and Carpenter, 1991) help diazotrophic organisms to prevent oxygen inhibition. Some diazotrophs also live in symbiosis with diatoms and dinoflagellates (i.e. the cianobacterium Richelia). Anaerobic microniches in aggregates of organic matter can also host significant $\mathrm{N}_{2}$ fixation, especially in post bloom periods when bacterial abundance in organic aggregates increases (Riemann et al., 2000). Another possibility is to alternate overnight $\mathrm{N}_{2}$ fixation with oxygenic photosynthesis during the day (Berman-Frank et al., 2007) or using photofermentative metabolisms allowing fixing $\mathrm{N}_{2}$ during $24 \mathrm{~h}$ such as UCYN-A (Tripp et al., 2010; Zehr et al., 2008).

$\mathrm{N}_{2}$ fixation can be limited by iron ( $\mathrm{Fe}$ ), which is an essential cofactor required in large quantities for this process (Raven, 1988; Falkowski, 1997). Nutrients such as phos-
BGD

11, 17151-17185, 2014

Nitrogen fixation in

the Southern Ocean

M. L. González et al.

Title Page

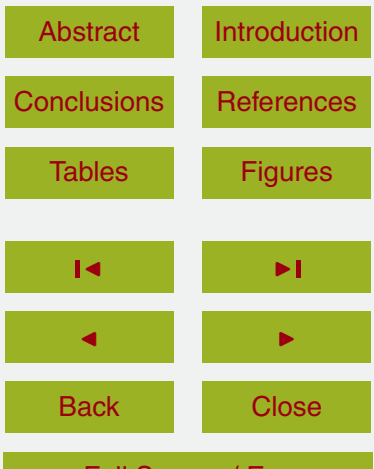

Full Screen / Esc

Printer-friendly Version

Interactive Discussion 
phate $\left(\mathrm{PO}_{4}^{3-}\right)$, has been suggested to co-limit diazotrophy along with $\mathrm{Fe}$ (Mills et al., 2004). The presence of inorganic nitrogen $\left(\mathrm{NH}_{4}^{+}\right.$and $\left.\mathrm{NO}_{3}^{-}\right)$in high concentrations could also inhibit this process. However, there is substantial disagreement on this last point, because of contradictory results with cultivated strains and diazotrophic activity reports

5 in environments with high concentrations of DIN (Mehta et al., 2003) and in productive coastal areas with $\mathrm{NO}_{3}^{-}$concentrations higher than $5 \mathrm{mmol} \mathrm{L}^{-1}$ (Voss et al., 2004; Fernandez et al., 2011; Riemann et al., 2010; Bird et al., 2005). These facts suggest that $\mathrm{N}_{2}$ fixation requires relatively large inputs of energy, reducing power, auxiliary antioxidant enzymes and metallic co-factors such as iron and molybdenum in order to 10 function (Kustka et al., 2003; Raven, 1988).

Around $20 \%$ of the global ocean shows High Nutrients Low Chlorophyl (HNLC) conditions (Blain et al., 2008a; Goeyens et al., 1998). Although the Southern Ocean is one of the largest HNLC areas of the world, natural and massive phytoplankton blooms occur annually in South Georgia, Crozet and Kerguelen Islands (Blain et al., 2007, 2008b;

15 Pollard et al., 2007) due to natural iron fertilization. The Kerguelen area in particular has a deep reservoir of Fe coming from sediment contribution, biogenic particles regeneration and possibly lithogenic Fe dissolution (Chever et al., 2010). Natural Fe-fertilization efficiency can be 10 to 150 times higher than artificial Fe-fertilization with respect to atmospheric $\mathrm{CO}_{2}$ sequestration bellow $200 \mathrm{~m}$ (Blain et al., 2007). This area provides a natural laboratory for studying scientific questions currently pressing the knowledge of the regulation of marine $\mathrm{N}_{2}$ fixation. Temperature and physical forcing (particularly mesoscale activity) as a limiting factor needs to be better understood, as it is the occurrence of $\mathrm{N}_{2}$ fixation in environments with micro molar concentrations of DIN and DIP. More importantly, its regulation via Fe availability and $\mathrm{P}$ and the effect of ammonium production via diazotrophic activity on the local $\mathrm{N}$ cycle need to be explored.

This study aims to investigate the occurrence of diazotrophic activity in naturally fertilized waters off the Kerguelen plateau and its relationship with Fe availability in natural fertilization conditions. The study area has attracted attention in the past, such as the project KEOPS1 that performed a detailed study of two contrasting sites, one located in

BGD

$11,17151-17185,2014$

Nitrogen fixation in

the Southern Ocean

M. L. González et al.

Title Page



Full Screen / Esc

Printer-friendly Version

Interactive Discussion

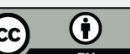


iron-fertilized waters above the plateau, and one located in offshore HNLC waters. The data for the present study were obtained from the KEOPS2 project that extended its study region to different sites located in iron fertilized waters east of Kerguelen Island.

\section{Materials and methods}

\section{$5 \quad 2.1$ Sampling}

The KEOPSII cruise was conducted between October and November 2011 (R/V Marion Dufresne) in the region of Kerguelen Islands in the Southern Ocean $\left(49.25^{\circ} \mathrm{S}\right.$, $69.58^{\circ} \mathrm{E}$; Fig. 1). The sampling strategy included two transects and four "process" stations illustrated in Fig. 1: St. R-2 in HNLC waters as a reference station, A3-2 above 10 the Kerguelen plateau, E-4W at the break of the plateau and F-L north of the Polar Front. A pseudo-Lagrangian study was also carried out in a stationary meander of the polar front characterized by strong mesoscale activity, hereafter referred as station $\mathrm{E}$ (Zhou et al., 2014). Four visits were carried out over one month time (E-1, E-3, E-4E, and E-5; Blain et al., 2014).

\section{$2.2 \mathrm{~N}_{2}$ fixation rates}

Experiments were done at all process stations and at the pseudo-Lagrangian stations "E".

Physical-chemical parameters were obtained with a CTDO rosette (SBE 32) equipped with $24 \times 10 \mathrm{~L}$ Niskin bottles. Samples were taken from the niskin bottles at 7 depth levels between the surface and the base of the euphotic zone.

Natural abundances of $\mathrm{N}$ isotopes $\left({ }^{15} \mathrm{~N} /{ }^{14} \mathrm{~N}\right)$ in particulate organic matter (POM) were determined at the same stations and depth levels as $\mathrm{N}_{2}$ fixation experiments were carried out. The isotopic composition expressed as $\delta^{15} \mathrm{~N}$ is used as a reference natural enrichment in ${ }^{15} \mathrm{~N}$ relative to ${ }^{14} \mathrm{~N}$ that will be compared to the corresponding
BGD

$11,17151-17185,2014$

Nitrogen fixation in

\section{the Southern Ocean}

M. L. González et al.

Title Page

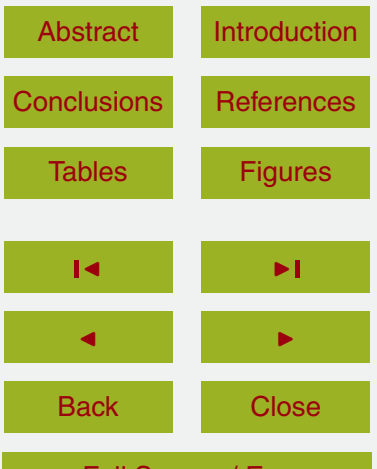

Full Screen / Esc

Printer-friendly Version

Interactive Discussion 
${ }^{15} \mathrm{~N}$ signal in $\mathrm{N}_{2}$ fixation calculations, therefore avoiding the use of literature values (Montoya et al., 1996). For doing so, seawater samples (1 L in duplicate) were filtered using a vacuum pump system at each depth through $0.7 \mu \mathrm{m}$ precombusted glass fiber filters $\left(450^{\circ} \mathrm{C}-12 \mathrm{~h}\right)$. Filters were then dried at $60^{\circ} \mathrm{C}$ and stored in similar conditions until laboratory analysis by mass spectrometry (Termo Finnigan delta Plus).

Profiles of $\mathrm{N}_{2}$ fixation were obtained at the 4 process stations described above and also during visits to pseudo-Lagrangian station "E" (Fig. 1, 8 sampling stations in total). Water samples (prefiltered by $25 \mu \mathrm{m}$ ) were taken in $1 \mathrm{~L}$ Nalgene bottles with septum caps, which were enriched with $2 \mathrm{~mL}$ of gas ${ }^{15} \mathrm{~N}_{2}$ (Montoya et al., 1996) injected with

10 a gas tight syringe. After agitation, samples were incubated for $24 \mathrm{~h}$ using on deck incubators that simulated light attenuation at different depth (black, 0.01, 0.3, 1, 4, 16, $25,45,75 \%$, Lee filters ${ }^{\circledR}$ ). Temperature was controlled by circulating surface seawater. Incubations were finished by filtration immediately after enrichment (T0) and after $24 \mathrm{~h}$ (Tf). Additionally, incubations were done for 2 size fractions (total and $<5 \mu \mathrm{m}$ ) with 15 an intermediate sampling time after $12 \mathrm{~h}$ of incubation. ${ }^{15} \mathrm{~N}_{2}$ incubations were filtered through a peristaltic system using precombusted glass fiber filters (GF/F) of $0.7 \mu \mathrm{m}$ pore $\left(450^{\circ} \mathrm{C}\right.$ for $\left.12 \mathrm{~h}\right)$. Filters were recovered and dried at $60^{\circ} \mathrm{C}$ for $24 \mathrm{~h}$. Subsequently, filters were kept at $60{ }^{\circ} \mathrm{C}$ until laboratory analysis through the IRMS (Isotope Ratio Mass Spectrometer Delta Plus, Finnigan). Rates were estimated according to previous studies (Fernandez et al., 2011; Montoya et al., 1996) and will be expressed as daily rates as $\mathrm{nmolL}^{-1} \mathrm{~d}^{-1}$.

\subsection{Nutrients and picoplankton abundance}

Nutrient samples $(10 \mathrm{~mL})$ for the determination of $\mathrm{NO}_{3}^{-}, \mathrm{NO}_{2}^{-}$, and $\mathrm{PO}_{4}^{3-}$ were filtered through $0.7 \mu \mathrm{m}(\mathrm{GF} / \mathrm{F})$ and analyzed on board with a Scalar autoanalyzer (Blain et al., 2014).

Samples for picoplankton abundance were collected on $2 \mathrm{~mL}$ cryotubes $(1350 \mu \mathrm{L}$ seawater and $150 \mu \mathrm{L}$ of $1 \%$ gluteraldehyde) and were frozen in liquid nitrogen. Sam-

BGD

$11,17151-17185,2014$

Nitrogen fixation in

the Southern Ocean

M. L. González et al.

Title Page

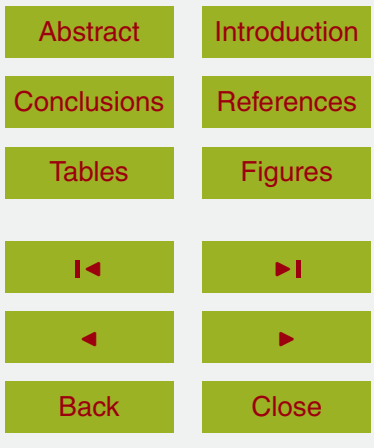

Full Screen / Esc

Printer-friendly Version

Interactive Discussion 
ples were then stored at $-80^{\circ} \mathrm{C}$ for subsequent analysis using a BD FACSCalibur flow cytometer (Christaki et al., 2014; Marie et al., 2000; Vaulot et al., 1989).

\subsection{Community composition of diazotrophs}

Water samples were collected at station E-1 from $20 \mathrm{~m}$ depth for molecular character5 ization of the diazotroph community. In spite of an extended sampling effort $(1 \mathrm{~L}$ water filtered at each process station and depth), amplification was only effective at station $\mathrm{E}-1$ using large volume sampling filters. The following protocol corresponds to this effective sampling.

Between 15 and $20 \mathrm{~L}$ of prefiltered seawater $(200$ and $5 \mu \mathrm{m}$ ) was filtered onto $0.2 \mu \mathrm{m}$ SuporPlus membranes $\left(142 \mathrm{~mm}\right.$ diameter) and stored at $-80^{\circ} \mathrm{C}$. All nucleic acid extractions where performed in triplicates by dividing the filters as described in a parallel study (Beier et al., 2014). Cellular lysis was performed with Proteinase $\mathrm{K}(2 \mathrm{~h}$ incubation, $56^{\circ} \mathrm{C}$ ) and followed by mechanical disruption using low binding zirconium beads (OPS Diagnostics, Lebanon, NJ, USA). DNA concentration was measured by Quant-it Picogreen dsDNA Assay (Invitrogen Life Technologies, Carlsbad, CA, USA) at $485 \mathrm{~nm}$ excitation wavelength and $535 \mathrm{~nm}$ emission wavelength in a Victor 1420 Multilabel counter (PerkinEl, emr, Waltham, MA, USA) run with Wallac 1420 3. Genomic DNA extracts were stored at $-20^{\circ} \mathrm{C}$ until further processing. To amplify nifH genes, a nested Polymerase Chain Reaction (nested-PCR) was performed using reported PCR primers (Zehr and McReynolds, 1989). The PCR mixture contained Go TAQ Green Master Mix 2x (Promega), $1 \mu \mathrm{L}$ of $25 \mu \mathrm{M}$ nifH3 ( $5^{\prime}$-ATR TTR TTN GCN GCR TA-3') and nifH4 (5'-TTY TAY GGN AAR GGN GG-3'), 10-40 ng $\mathrm{LL}^{-1}$ of DNA extract and the volume was adjusted with water to obtain a $25 \mu \mathrm{L}$ reaction. Thermal cycling for the first PCR was performed as follows: $5 \mathrm{~min}$ at $95^{\circ} \mathrm{C}, 30$ cycles of $1 \mathrm{~min}$ 25 at $95^{\circ} \mathrm{C}, 1 \mathrm{~min}$ at $50^{\circ} \mathrm{C}$, and $1 \mathrm{~min}$ at $72^{\circ} \mathrm{C}$, followed by a final extension step of $7 \mathrm{~min}$ at $72^{\circ} \mathrm{C}$. The second PCR was carry out by same reagent mixture as above with internal nifH primers [50] $1 \mu \mathrm{L}$ of $25 \mu \mathrm{M}$ nifH1 (TGYGAYCCNAARGCNGA) and $1 \mu \mathrm{L}$ of $25 \mu \mathrm{M}$ nifH2 (ADNGCCATCATYTCNCC), however, the template volume was reduced 17158
BGD

$11,17151-17185,2014$

Nitrogen fixation in

the Southern Ocean

M. L. González et al.

Title Page

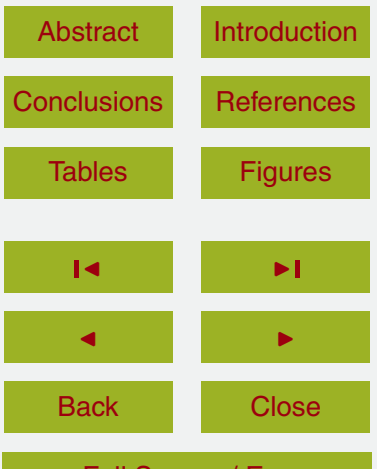

Full Screen / Esc

Printer-friendly Version

Interactive Discussion 
by $50 \%$. Second-round reactions were amplified with one denaturation step of $5 \mathrm{~min}$ at $95^{\circ} \mathrm{C}, 30$ cycles of $95^{\circ} \mathrm{C}$ for $1 \mathrm{~min}, 57^{\circ} \mathrm{C}$ for $1 \mathrm{~min}$ and $72^{\circ} \mathrm{C}$ for $1 \mathrm{~min}$, and a final $7 \mathrm{~min}$ extension cycle at $72^{\circ} \mathrm{C}$. Several replicates of these reactions $(n=3)$ were combined and concentrated using the E.Z.N.A. Cycle-Pure Kit (Omega Bio-Tek). In both PCRs, 5 negative and positive control using water and Trichodesmiun sp. DNA extract, respectively, were run together with the samples. The purified PCR products were cloned using the pGEM-T Easy vector systems according to the manufacturer's instructions (Promega). Sequencing was done by Macrogen Inc. (Korea).

Phylogenetic analyses were performed using 34 valid sequences. The sequences 10 were first vector trimmed. Low quality sequences where removed using SeqMan DNAstar software. Curated sequences were then aligned in the nucleotide space with MUSCLE (Edgar, 2004) and similarities were computed using Bosque software (Ramirez-Flandes and Ulloa, 2008). One operational taxonomic units (OTUs) were estimated using $>98 \%$ of nucleotide similarity. Phylogenetic trees were constructed us-

15 ing a maximum-likelihood algorithm by Fast Tree (Price et al., 2010) (Bosque software, Ramirez-Flandes and Ulloa, 2008) using the OTU retrieved from the study area together with cultured representatives having nifH and similar environmental sequences retrieved from NCBI Blast. Sequence of the representative OTU was deposited in the GenBank database under accession number KM242081.

\section{Results}

\subsection{Hydrographic conditions}

The study area holds a complex structure of circulation, water masses and fronts. The stations located north of the polar front (TNS1, 2, TEW1, 2, 7, 8 and F-L) are influenced by AASW (Antarctic Surface Water) and AAIW (Antarctic Intermediate Water) reflected in high temperatures $\left(4^{\circ} \mathrm{C}\right)$, low salinity $(<34)$ and low density $\left(<27 \mathrm{~kg} \mathrm{~m}^{-3}\right)$ in the upper $200 \mathrm{~m}$ (Fig. $2 \mathrm{a}$ and $\mathrm{c}$ ). The stations south of the polar front however (TNS3-10,

Nitrogen fixation in

the Southern Ocean

M. L. González et al.

Title Page

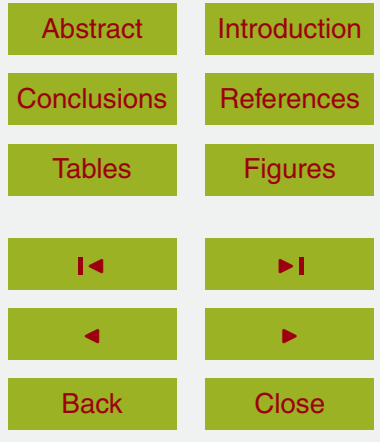

Full Screen / Esc

Printer-friendly Version

Interactive Discussion

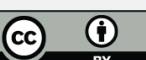


A3-2, TEW3-6 and "E" stations) are mainly influenced by Winter Waters (WW) characterized by low temperatures $\left(<2^{\circ} \mathrm{C}\right)$, lower salinity $(>34)$ and density between 27 and $27.5 \mathrm{~kg} \mathrm{~m}^{-3}$ in the upper $200 \mathrm{~m}$ (Fig. $2 \mathrm{a}$ and c). The "E" stations showed a temperature increment $\left(2.5\right.$ to $\left.>3.5^{\circ} \mathrm{C}\right)$ and a density decrease $\left(>27\right.$ to $\left.<26.95 \mathrm{~kg} \mathrm{~m}^{-3}\right)$ in the first $5100 \mathrm{~m}$ over time (from E-1 to E-5; Fig. 3a).

The Mixed Layer Depth (MLD) showed high variability among stations (Park et al., 2014). Values of MLD in the HNLC area (R-2 station) and above the plateau (A3-2 station) were deeper $(123 \mathrm{~m})$ than the F-L station which showed a strong stratification and a shallow MLD (40 m; Table 1). The Photic Zone was defined as the depth where 10 Photosynthetically Active Radiation (PAR) reaches $1 \%$ and was also deeper at R-2 $(92 \mathrm{~m})$ than A3-2 (38 m) compared to F-L (26 m; Table 1). For the Lagrangian stations "E", MLD values were variable, with a maximum depth at the fourth visit E-4E $(80 \mathrm{~m})$ and minimum at the final sampling $E-5(38 \mathrm{~m})$. On the contrary, Ze values were lower at E-4E (48 m) compared to E-5 (68 m; Table 1).

\subsection{Nutrients and fluorescence distribution}

The general distribution of $\mathrm{NO}_{3}^{-}, \mathrm{NO}_{2}^{-}$, and $\mathrm{PO}_{4}^{3-}$ as well as stoichiometric conditions in the study area are reported in detail in this issue (Blain et al., 2014). The distribution of $\mathrm{N}^{*}$ (Gruber and Sarmiento, 1997; Michaels et al., 1996) showed a slight increment from 0 to $2 \mu \mathrm{mol} \mathrm{L}^{-1}$ south of the TNS transect over $150 \mathrm{~m}$ and a remarkable increment over 20 the MLD $\left(0\right.$ to $\left.8 \mu \mathrm{molL}^{-1}\right)$ at stations north of the polar front (TEW7, 8 and F-L stations; Fig. $2 \mathrm{~b}$ and $\mathrm{d}$ ). This indicates an excess of $\mathrm{N}$ (probably $\mathrm{NO}_{3}^{-}$) with respect to $\mathrm{PO}_{4}^{3-}$ in an area where a large diatom bloom developed during this study and high rates of nitrification were also detected (Cavagna et al., 2014; Lasbleiz et al., 2014). Stations "E" showed a decreasing evolution of $\mathrm{N}^{*}$ values over time (Fig. $3 \mathrm{~b}$ ) which match the 25 increase in fluorescence (Fig. 3c) and nutrient utilization as the blooms develops. The vertical distribution of nutrients for all process stations is reported in Fig. 4. The reference station $\mathrm{R}-2$ showed constant values of $\mathrm{NO}_{3}^{-}+\mathrm{NO}_{2}^{-}$and $\mathrm{PO}_{4}^{3-}$ concentrations in
BGD

$11,17151-17185,2014$

Nitrogen fixation in

the Southern Ocean

M. L. González et al.

Title Page

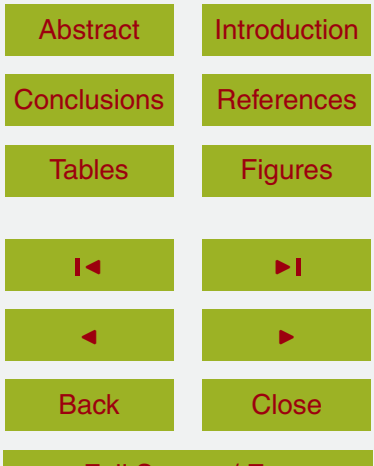

Full Screen / Esc

Printer-friendly Version

Interactive Discussion 
the first $200 \mathrm{~m}$ (25 and $2 \mu \mathrm{molL}^{-1}$ respectively). $\mathrm{NH}_{4}^{+}$remained at $0.2 \mu \mathrm{mol} \mathrm{L}^{-1}$ values in the MLD $(120 \mathrm{~m})$ and decreased rapidly to near 0 values at $200 \mathrm{~m}$ (Fig. 4e). Station A3-2 showed $\mathrm{NO}_{3}^{-}+\mathrm{NO}_{2}^{-}$concentrations near $25 \mathrm{\mu mol} \mathrm{L}^{-1}$ in surface waters and close to $30 \mu \mathrm{mol} \mathrm{L}^{-1}$ at $150 \mathrm{~m}$. $\mathrm{PO}_{4}^{3-}$ concentrations were constantly around $2 \mu \mathrm{mol} \mathrm{L}^{-1}$ in the 5 MLD while high values of $\mathrm{NH}_{4}^{+}$were observed in surface $\left(>0.2 \mu \mathrm{molL}{ }^{-1}\right.$ down to $80 \mathrm{~m}$ depth) as well as deeper layers $\left(0.1 \mu \mathrm{molL}^{-1}\right.$ at $150 \mathrm{~m}$ depth, Fig. $\left.4 \mathrm{f}\right)$. Station $\mathrm{E}-4 \mathrm{~W}$ showed high levels of $\mathrm{NO}_{3}^{-}+\mathrm{NO}_{2}^{-}$and $\mathrm{PO}_{4}^{3-}$ distributed homogeneously in the MLD (25-27 and 1.5-2 $\mathrm{mmol} \mathrm{L}^{-1}$ respectively, Fig. 4g). However ammonium concentrations were close to 0 in surface waters but showed a dramatic increase to $0.35 \mu \mathrm{molL}^{-1}$ over $10100 \mathrm{~m}$ (Fig. 4g). Interestingly, station F-L showed the lowest surface concentrations of $\mathrm{NO}_{3}^{-}+\mathrm{NO}_{2}^{-}\left(20 \mu \mathrm{mol} \mathrm{L}^{-1}\right)$, which increased in subsurface layers to values exceeding $30 \mu \mathrm{mol} \mathrm{L}^{-1} \cdot \mathrm{PO}_{4}^{3-}$ concentrations were also below average values $\left(1.2 \mu \mathrm{molL}^{-1}\right)$ in surface waters that increased to $2 \mu \mathrm{mol} \mathrm{L}^{-1}$ at $200 \mathrm{~m}$. Ammonium concentrations showed a distinct subsurface peak of $0.5 \mu_{\mathrm{mol} \mathrm{L}}{ }^{-1}$ at $60-80 \mathrm{~m}$ depth. Deeper values however were close to detection limit and reached 0 at $200 \mathrm{~m}$ (Fig. 4h). Concerning station "E", a decrease in macronutrients was observed with time while the nutricline deepened from surface at $\mathrm{E}-1$ to $100 \mathrm{~m}$ depth during the last visit (E-5). $\mathrm{A} \mathrm{NH}_{4}^{+}$subsurface maximum was detected $\left(0.4\right.$ to $\left.0.65 \mathrm{umol} \mathrm{L}^{-1}\right)$ which was twice as high as surface values $\left(0.2\right.$ to $\left.0.3 \mu \mathrm{mol} \mathrm{L}^{-1}\right)$ suggesting an increase in remineralization in subsurface waters (Blain et al., 2014).

In general, a phytoplankton bloom with fluctuating biomass in time and space was developed at all stations, except for station R-2 (Fig. 4a) located in a permanent HNLC area (Blain et al., 2014; Lasbleiz et al., 2014). Station A3-2 showed surface fluorescence values $>2 \mathrm{\mu g} \mathrm{L}^{-1}$ (Fig. $4 \mathrm{~b}$ ) with a main contribution of microphytoplankton with respect to picophytoplankton (Lasbleiz et al., 2014). Moreover, bacterioplankton was consistently present throughout the water column and characterized by a high relative abundance of HNA (High Nucleid Acid) bacteria at A3-2 (Fig. 4b). The highest fluorescence values $\left(>4 \mu \mathrm{gL}^{-1}\right)$ were found north of the polar front (F-L station; Fig. $\left.4 \mathrm{~d}\right)$,
BGD

$11,17151-17185,2014$

Nitrogen fixation in

the Southern Ocean

M. L. González et al.

Title Page

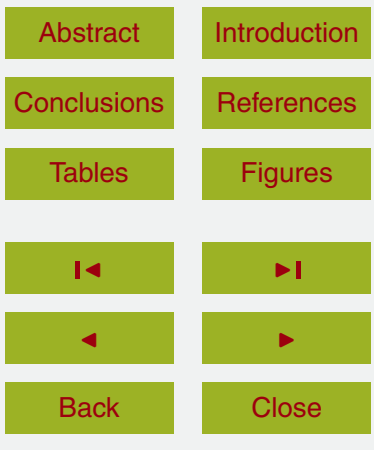

Full Screen / Esc

Printer-friendly Version

Interactive Discussion 
with a main contribution of large diatoms (Lasbleiz et al., 2014). Also at F-L, bacterial abundance was high in the MLD (Fig. 4d) and included a high percentage of HNA and nanoeukaryotes which coincide with the distribution of Chlorophyll a (Christaki et al., 2014). For "E" stations fluorescence showed an increment from E-1 to E-5 $(<0.75$ to $\left.5>1 \mathrm{~g} \mathrm{~L}^{-1}\right)$ and a deepening of its vertical distribution $\left(0.75 \mathrm{\mu g} \mathrm{L}^{-1}\right.$ isoline) following the MLD (Fig. 3; Table 1). The contribution of picoeukariotes and nanoeukariotes were maximum at the beginning and at the end of sampling at the "E" stations and the microphytoplankton community had a similar behavior (Lasbleiz et al., 2014) suggesting a mixed phytoplankton community. Bacterioplankton showed a maximum abundance $10\left(>400 \times 10^{3}\right.$ cells $\left.\mathrm{mL}^{-1}\right)$ at E-4 over $50 \mathrm{~m}$ which is consistent with the distribution of fluorescence (Fig. 3).

\subsection{Nitrogen fixation rates}

$\mathrm{N}_{2}$ fixation was detected at all the sampled stations with rates ranging between 0.4 (E-1, $129 \mathrm{~m}$ and $0 \%$ incident light) and $20.1 \mathrm{nmol} \mathrm{NL}^{-1} \mathrm{~d}^{-1}$ (F-L, $2 \mathrm{~m}$ and $75 \%$ incident 5 light), with high spatial and temporal variability.

The reference station $\mathrm{R}-2$ and station A3-2 showed similar average rates $(4.45 \pm 2.6$ and $3.2 \pm 2.8 \mathrm{nmolNL}^{-1} \mathrm{~d}^{-1}$, respectively) over the MLD (Table 1). $\mathrm{N}_{2}$ fixation at these stations was concentrated mainly in the photic zone with values ranging between 1.05 and $7.9 \mathrm{nmol} \mathrm{NL}^{-1} \mathrm{~d}^{-1}$ at R-2 and between 2.09 and $6.49 \mathrm{nmolNL}^{-1} \mathrm{~d}^{-1}$ at A3-2. How20 ever, rates at R-2 station increased ( 1.05 to $\left.3.13 \mathrm{nmol} \mathrm{NL}^{-1} \mathrm{~d}^{-1}\right)$ under $1 \%$ light which also coincide with a dFe increment (Quéroué et al., 2014). Bacterial abundance and fluorescence for R-2 are constant and low in the MLD $\left(<300 \times 10^{3}\right.$ cells mL $^{-1}$ and $<0.5 \mathrm{\mu g} \mathrm{L}^{-1}$ respectively) as well as nutrients (Fig. $4 \mathrm{a}$ and e). But in A3-2, higher bacterioplankton and fluorescence values were observed $\left(300-400 \times 10^{3}\right.$ cells mL $^{-1}$ and

Station E-4W station was located west of the meander and in the break of plateau. Average $\mathrm{N}_{2}$ fixation rates reached $5.41 \pm 2.2 \mathrm{nmol} \mathrm{NL}^{-1} \mathrm{~d}^{-1}$ over the MLD (Table 1), with 
high values $\left(8.56 \mathrm{nmolNL}^{-1} \mathrm{~d}^{-1}\right)$ at $12 \mathrm{~m}$ and $16 \%$ incident light (Fig. 4c). The highest $\mathrm{N}_{2}$ fixation rates in this study were detected at station $\mathrm{F}-\mathrm{L}$, with an average rate of $10.27 \pm 7.5 \mathrm{nmol} \mathrm{NL}^{-1} \mathrm{~d}^{-1}$ over the MLD (Table 1), the maximum values were obtained at surface (20.1 nmol NL ${ }^{-1} \mathrm{~d}^{-1}$ at $2 \mathrm{~m}$ and $75 \%$ incident light) and decreased with depth $5 \quad\left(2.2 \mathrm{nmol} \mathrm{NL}^{-1} \mathrm{~d}^{-1}\right.$ at $20 \mathrm{~m}$ and $4 \%$ incident light, Fig. $\left.4 \mathrm{~d}\right)$. Fluorescence values at both stations were high compared to R-2 and A3-2, with values between 2 and $4 \mathrm{\mu g} \mathrm{L}^{-1}$ for $\mathrm{E}-4 \mathrm{~W}$ and $\mathrm{F}-\mathrm{L}$ respectively, which was consistent with bacterial abundance $(>600 \times$ $10^{3}$ cells $^{-1}$ ) over MLD (Fig. $4 \mathrm{c}$ and d). The vertical nutrient distribution showed DIN utilization in surface waters and a rapid increase in concentrations under the MLD. 10 Also, at both stations a subsurface $\mathrm{NH}_{4}^{+}$peak $\left(0.35\right.$ and $0.42 \mu \mathrm{molL}^{-1}$ respectively) was observed (Fig. $4 \mathrm{~g}$ and $\mathrm{h}$ ). It should be noted that the MLD and photic layer were shallow compared to R-2 and A3-2 (Fig. 4a-c and d, Table 1).

During successive measurements at station "E", $\mathrm{N}_{2}$ fixation rates coincided with decreasing values of $\delta^{15} \mathrm{~N}$ in particulate organic matter (POM; Fig. $5 a$ and b), which 15 is consistent with the isotopic fractionation associated to POM created via $\mathrm{N}_{2}$ fixation (Zahn et al., 1994). The highest rates were detected at the beginning and end of the time series (average over the MLD $3.5 \pm 2.8 \mathrm{nmolNL}^{-1} \mathrm{~d}^{-1}$ for $\mathrm{E}-1$ and $4.8 \pm 1.2 \mathrm{nmolNL}^{-1} \mathrm{~d}^{-1}$ for E-5; Table 1) which coincided with the fluorescence distribution (Fig. 3), particularly with picoeukaryotes and nanoeukaryotes. Moreover, the highest rates were observed within the photic layer (Table 1) with values between 1.8$7.6 \mathrm{nmolNL} \mathrm{N}^{-1} \mathrm{~d}^{-1}$, while subsurface rates reached $1.1 \mathrm{nmolNL} \mathrm{N}^{-1} \mathrm{~d}^{-1}$ in average down to $140 \mathrm{~m}$ (Fig. 5a)

A multivariate Principal Components Analysis (PCA) indicated that the variables that mainly influenced the physical-chemical conditions at the contrasting stations sampled were $\mathrm{PO}_{4}^{3-}, \mathrm{NO}_{3}^{-}$, density, temperature and Chlorophyll a. Station F-L was associated mainly with temperature, Chlorophyll $a$, dFe (data reported in Queroué et al., 2014) and $\mathrm{NH}_{4}^{+}$. Stations $\mathrm{A} 3-2, \mathrm{E}-3$ and $\mathrm{E}-4 \mathrm{~W}$ on the other hand were associated mainly with $\mathrm{PO}_{4}^{3-}, \mathrm{NO}_{3}^{-}$and density, while $\mathrm{R}-2$ and E-5 were negatively related to these variables. This coincides with the influence of Antarctic Surface Waters (AASW) and Winter Wa17163
BGD

$11,17151-17185,2014$

Nitrogen fixation in

the Southern Ocean

M. L. González et al.

Title Page

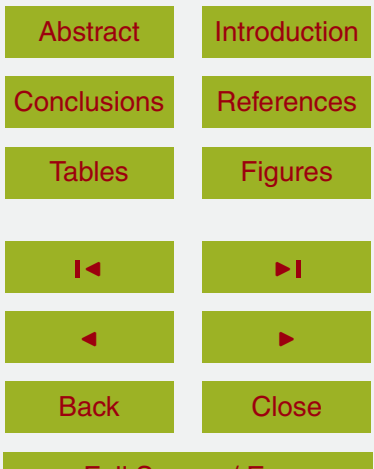

Full Screen / Esc

Printer-friendly Version

Interactive Discussion 
ters (WW), as well as with the nutrient distribution and utilization at each zone. The correlation between PC1 and $\mathrm{N}_{2}$ fixation rates over the MLD was significant $(p=0.01)$ with a negative correlation coefficient $(r=-0.9)$. Therefore $\mathrm{N}_{2}$ fixation seems overall correlated with Chlorophyll $\mathrm{a}, \mathrm{dFe}, \mathrm{NH}_{4}^{+}$and temperature.

\section{3.3.1 Size fraction and time course experiments}

During time course experiments of $\mathrm{N}_{2}$ fixation, rates were obtained at 12 and $24 \mathrm{~h}$ incubation times (Fig. 6a and b), with different incident light levels (75, 25 and 1\%) and size fractionation (total community and $<5 \mu \mathrm{m}$ ). At st R-2 there were no significant differences between treatments although an increase in total community rates 10 was observed $\left(1.19 \pm 0.8 \mathrm{nmolNL}^{-1} \mathrm{~d}^{-1}\right.$ at $12 \mathrm{~h}$ to $3.8 \pm 0.9 \mathrm{nmolNL}^{-1} \mathrm{~d}^{-1}$ at $\left.24 \mathrm{~h}\right)$ with respect to the lower size fraction at $24 \mathrm{~h}$ (Fig. 6a). At st A3-2, a significant difference was observed over time for 75 and $25 \%$ light levels $(p=0.002$, Tukey test: 0.0016 and 0.027 , respectively) with maximum rates at $12 \mathrm{~h}\left(3.39 \pm 0\right.$ and $4.80 \pm 2.4 \mathrm{nmolNL}^{-1} \mathrm{~d}^{-1}$, respectively) and a decline at $24 \mathrm{~h}\left(2.55 \pm 0.7\right.$ and $2.02 \pm 1.5 \mathrm{nmolNL}^{-1} \mathrm{~d}^{-1}$, respectively). No significant differences between light intensities were found, but the decrease was less significant at $75 \%$ (Fig. 6b). At st E-3 no significant differences were observed, but the total community incubated at $75 \%$ light had a positive evolution over time $\left(3.65 \pm 0 \mathrm{nmolNL}^{-1} \mathrm{~d}^{-1}\right.$ at $12 \mathrm{~h}$ to $5.1 \pm 1.4 \mathrm{nmolNL}^{-1} \mathrm{~d}^{-1}$ at $24 \mathrm{~h}$ ) while the total community incubated at $1 \%$ light showed decreasing rates at $24 \mathrm{~h}$. Finally, at F-L station the highest rates were observed for both size fraction and both light intensities. Significant differences between both size fractions were obtained ( $t$ test $p=0.039$ ), where the maximum rates were at $12 \mathrm{~h}$, with a decay at $24 \mathrm{~h}$ for the total community. Also rates from the total community incubated at 75 and $25 \%$ light has a significant increase between 0 and $12 \mathrm{~h}$ (ANOVA, $p<0.001$ Tukey test, $p<0.001$ ) reaching to $259.07 \pm 0$ and $7.31 \pm 0.3 \mathrm{nmolNL}^{-1} \mathrm{~d}^{-1}$ respectively. Overall, the lack of significant differences between size fraction suggest a dominant role of $<5 \mu \mathrm{m}$ diazotrophs in this area.
BGD

Nitrogen fixation in the Southern Ocean

M. L. González et al.

Title Page

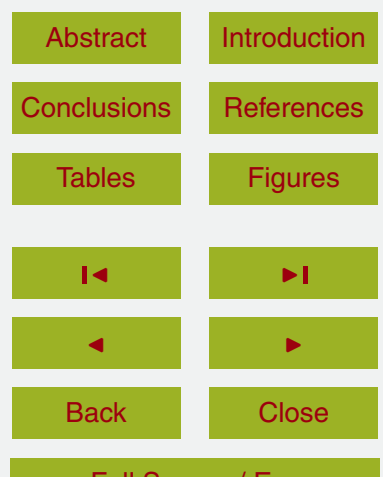

Full Screen / Esc

Printer-friendly Version

Interactive Discussion 


\subsection{Community composition of diazotrophs}

We detected the nifH gene only at $20 \mathrm{~m}$ in E-1 station. The community structure was characterized by low diversity represented by 1 Operational Taxonomic Unit (OTU), which included 34 sequences with a $>98 \%$ similarity in the nucleotide space. The 5 phylogenetic analysis showed that all sequences are affiliated to Cluster I and to the subcluster $1 \mathrm{~J}, 1 \mathrm{U}$ and $1 \mathrm{~K}$ previously reported by (Zehr et al., 2003), which are associated to heterotrophic bacteria. The OTU obtained in this study was similar to sequences recovery from diverse ecosystems (Fig. 7) such as the Eastern Tropical South Pacific (Fernandez et al., 2011), North Pacific (Zehr et al., 2001), Mediterranean Sea

10 (Man-Aharonovich et al., 2007) and some sequences derived from symbionts of marine organisms such as dinoflagellates (Farnelid et al., 2010). On the other hand, the sequences obtained were not related to possible contaminants previously reported (Turk-Kubo et al., 2013).

\section{Discussion}

15 This study provides the first evidence of high $\mathrm{N}_{2}$ fixation rates for the Southern Ocean, the largest HNLC zone in the global ocean. It shows the occurrence of this process in a variety of Fe-fertilized conditions, including HNLC and iron fertilized waters at the polar front.

Temperature has been suggested as a limitation factor for the distribution of diazotrophic communities, since the highest rates reported to date are associated to temperate waters (Karl et al., 2002; LaRoche and Breitbarth, 2005). However through this study we demonstrated that $\mathrm{N}_{2}$ fixation can also occur at low temperatures $\left(<4{ }^{\circ} \mathrm{C}\right)$, which is in concordance with recent reports of $\mathrm{N}_{2}$ fixation in the Artic zone (Blais et al., 2012). We therefore support the idea that $\mathrm{N}_{2}$ fixation is an ubiquitous process.

25 Although we obtained high $\mathrm{N}_{2}$ fixation rates, we also observed high spacial and temporal variability. The $\mathrm{N}_{2}$ fixation rates detected in the Southern Ocean, in general,

Nitrogen fixation in

the Southern Ocean

M. L. González et al.

Title Page



Full Screen / Esc

Printer-friendly Version

Interactive Discussion

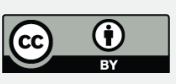


were higher than in other HNLC and oligotrophic areas, (up to 5 times higher; Table 2) considering integrated values. Moreover our average integrated rate $\left(265 \mu \mathrm{mol} \mathrm{m}^{-2} \mathrm{~d}^{-1}\right)$ for the study area are two orders of magnitude higher than rates reported for the Arctic (Blais et al., 2012) and Mediterranean sea (Yogev et al., 2011). High temporal and 5 spatial variability has indeed been reported for other marine ecosystems e.g. Eastern Tropical South Pacific including the Oxygen Minimum Zone (Dekaezemacker et al., 2013; Fernandez et al., 2011). Field experiments suggest that this variability can be linked to nutrients availability (mainly DIP and Fe) and environmental conditions (e.g. ENSO).

10 The role of Fe in controlling $\mathrm{N}_{2}$ fixation is centered in its importance as a co-factor for the nitrogenase enzyme (Mills et al., 2004; Dekaezemacker et al., 2013; Kustka et al., 2002). Several studies have been carried out in recent years, which included addition of different amounts of Fe to microcosms experiments and measurements of $\mathrm{N}_{2}$ fixation rates over time. Results have been highly variable and unconclusive on the ultimate 15 regulation factor for this process (Sohm et al., 2011). However, a model study at global scale showed that $\mathrm{Fe}$ (as dust) is not the main controlling factor of this process (Luo et al., 2014). The KEOPS2 cruise allowed exploring the link between $\mathrm{Fe}$ and $\mathrm{N}_{2}$ fixation in naturally fertilized conditions, where the control was a permanent HNLC condition area, and stations with different Fe concentrations were sampled.

According to our PCA results, $\mathrm{N}_{2}$ fixation could be co-regulated by $\mathrm{dFe}$ and primary productivity off the Kerguelen plateau. Higher rates coincided with high levels of primary production and phytoplankton standing stock (Cavagna et al., 2014) which in turn is stimulated by Iron fertilization. Indeed, the strongest average rates found at F-L over the MLD $\left(10.27 \mathrm{nmol} \mathrm{L}^{-1} \mathrm{~d}^{-1}\right)$ could be related to a high dFe supply (Quéroué et al., 2014) which in turn favors high phytoplanktonic biomass $\left(>4 \mu \mathrm{gL}^{-1}\right)$ related with diatoms (Lasbleiz et al., 2014). Besides, in this station as well as the others, maximum rates coincided with high incident light (e.g. $20.1 \mathrm{nmolL}^{-1}$ found at $75 \%$ light for $F-L$ ) and a shallow MLD (Table 1). Remarkably, the highest $\mathrm{N}^{*}$ values were also found at $\mathrm{F}-\mathrm{L}\left(\sim 8 \mu \mathrm{mol} \mathrm{L}^{-1}\right)$ and could be partially explained by the active $\mathrm{N}_{2}$ fixation although its
BGD

$11,17151-17185,2014$

Nitrogen fixation in

the Southern Ocean

M. L. González et al.

Title Page

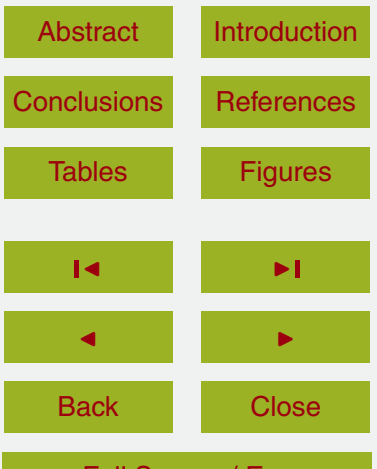

Full Screen / Esc

Printer-friendly Version

Interactive Discussion 
contribution is surely combined with that of other major processes such as nitrification (Cavagna et al., 2014). Stations $\mathrm{E}-4 \mathrm{~W}$ and A3-2 showed moderate $\mathrm{N}_{2}$ fixation rates (5.41 and $3.27 \mathrm{nmolL}^{-1} \mathrm{~d}^{-1}$, respectively, see Table 1). These rates also coincided with high phytoplankton stocks (Lasbleiz et al., 2014) although lower than F-L, and pre5 sented a different community structure of mainly large diatoms compared to $F-L$ and R-2.

Station R-2 showed a low phytoplankton biomass $\left(<1 \mu \mathrm{gL}^{-1}\right)$ and low dFe supply, thus we expected low $\mathrm{N}_{2}$ fixation rates. However, rates within the MLD (both station with similar MLD) were moderated and exceeded rates obtained at A3-2 (4.45 and $10 \quad 3.27 \mathrm{nmol} \mathrm{L}^{-1} \mathrm{~d}^{-1}$ average, respectively). This could be related to the phytoplankton community supported mainly by nano and picoplankton, and also by the deep MLD at both stations.

In parallel, the evolution observed at stations " $E$ " showed higher rates at the last visit, E-5, which coincided with fluorescence distribution (Fig. 4), changes in phytoplankton 15 community structure (Lasbleiz et al., 2014) and the ${ }^{15} \mathrm{~N}$ isotopic fractionation of POM (according to which low $\delta^{15} \mathrm{~N}$ values were found in POM at E-5 compared to E-1).

These records show that the magnitude and time variability of $\mathrm{N}_{2}$ fixation rates could be related with primary production and/or with phytoplankton community structure, and therefore with the availability and origin of dissolved organic matter in the system. This hypothesis is consistent with findings suggesting a relationship between $\mathrm{N}_{2}$ fixation rates in the Eastern and Tropical South Pacific and the availability (Dekaezemacker et al., 2013; Bonnet et al., 2013) and quality of DOM (Fernandez et al., 2014) derived from phytoplankton (although the rates found at the tropical HNLC area in the ETSP are 5 times lower than rates found in our study). The diazotrophic community $\mathrm{E}-1$ station (at the beginning of the bloom). The phylogenetic analysis showed one OTU corresponding to 33 sequences all within Cluster I and associated to subcluster $1 \mathrm{~J}, 1 \mathrm{U}$ and $1 \mathrm{~K}$, which are related to heterotrophic bacteria, which would support the idea of an important role of organic matter in the regulation of $\mathrm{N}_{2}$ fixation processes. These also

BGD

$11,17151-17185,2014$

Nitrogen fixation in

the Southern Ocean

M. L. González et al.

Title Page

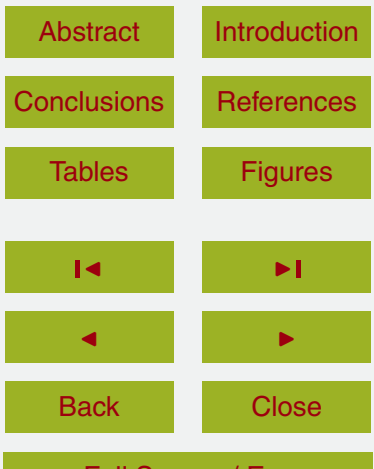

Full Screen / Esc

Printer-friendly Version

Interactive Discussion 
coincide with other phylogenetic studies mainly at South Pacific area where $\mathrm{N}_{2}$ fixation is dominated by heterotrophic diazotrophs (Fernandez et al., 2011; Halm et al., 2012; Dekaezemacker et al., 2013; Bonnet et al., 2013; Loescher et al., 2014). Considering the low diversity found we cannot dismiss the possibility of other diazotrophic organ5 isms such as cyanobacteria and/or symbionts. This suggestion is supported based on the heterogeneity observed in the Kerguelen bloom and the differential response of the diazotrophic community during the size-fractionation experiments which showed that larger fractions are enhanced during long incubations at some stations and light incidences including HNLC conditions (Fig. 6).

10 Although the limitation of $\mathrm{N}_{2}$ fixation by $\mathrm{Fe}$ and co-limitation by $\mathrm{Fe}$ and $\mathrm{PO}_{4}^{3-}$ e.g. (Mills et al., 2004; Dekaezemacker et al., 2013) is generally accepted, the occurrence of diazotrophy in HNLC conditions and in Fe fertilized water suggest that the role of $\mathrm{Fe}$ in the $\mathrm{N}_{2}$ fixation processes is indirect, mainly stimulating primary production and consequently diazotrophic activity by providing DOM from associated phytoplankton communities. Moreover the Fe limitation for diazotrophy is known to control diazotrophic cyanobacteria such as Trichodesmiun (Bonnet et al., 2009), which were not detected in this study. On the other hand, the dFe supply and the consequent phytoplankton bloom development were heterogeneous in magnitude, space and time during the KEOPS2 cruise (Quéroué et al., 2014). This variability mirrors the spatial and time variability of $\mathrm{N}_{2}$ fixation in the Kerguelen region. However, it is also possible that diazotrophic communities remained limited by dFe during the bloom in spite of DOM availability as heterotrophic bacterioplankton (the only diazotrophic group identified in this study) seems to be outcompeted for dFe by higher trophic levels during the fertilization event (Fourquez et al., 2014). It is evident that further efforts are necessary to achieve a better characterization of diazotrophic activity in the Southern Ocean.

The biological production at the HNLC area in the KEOPS study region (st R2 ) is mainly supported by regenerated production, which means that the $\mathrm{N}$ source for primary producers is primarily $\mathrm{NH}_{4}^{+}$compared to $\mathrm{NO}_{3}^{-}$uptake (Cavagna et al., 2014). The $N_{2}$ fixation rates found at $R-2$ (where the dFe supply is low and limits
BGD

11, 17151-17185, 2014

Nitrogen fixation in

the Southern Ocean

M. L. González et al.

Title Page

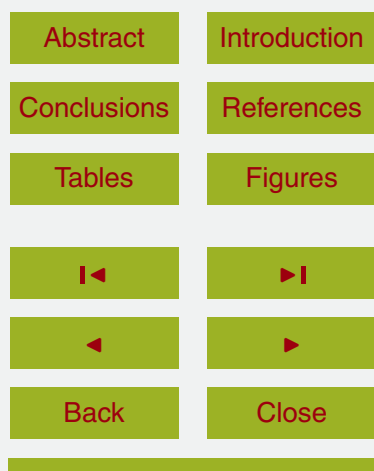

Full Screen / Esc

Printer-friendly Version

Interactive Discussion 
primary production) were in the same range of the A3-2 and "E" stations (meander area), which was unexpected. Overall, this $\mathrm{N}$ source should be a new source for primary producers in all conditions; therefore new production during the bloom could be underestimated and regenerated production overestimated. Considering an aver5 age $\mathrm{NO}_{3}$ uptake rate of $0.94 \mathrm{umolL}^{-1} \mathrm{~d}^{-1}, \mathrm{~N}_{2}$ fixation could add an additional $0.5 \%$ $\left(0.005 \mathrm{umol} \mathrm{L}^{-1} \mathrm{~d}^{-1}\right)$ to new primary production (corrected by nitrification using an average rate of 0.23 umol $^{-1} \mathrm{~d}^{-1}$, Fernandez unpublished data). Moreover, $\mathrm{N}_{2}$ fixation is likely to co-occur with nitrification, which was found over $200 \mathrm{~m}$ in the water column with high rates (Cavagna et al., 2014; Dehairs et al., 2014; Fernandez et al. unpub10 lished data). Ammonium by diazotrophy could support $20 \%$ of ammonium oxidation in the study area considered. In this context, if the entire $\mathrm{N}$ fixed by diazotrophy is transformed to $\mathrm{NO}_{3}^{-}$, this process could contribute to the excess of $\mathrm{N}$ observed at the end of the bloom (KEOPS1)

\section{Conclusions}

15 This is the first record of $\mathrm{N}_{2}$ fixation and a first phylogenetic approach of diazotrophic community for the Southern Ocean in a naturally Fe fertilized area. This contribution, combined to others studies confirm that diazotrophy is a ubiquitous processes. In addition, dFe concentrations had an indirect effect on $\mathrm{N}_{2}$ fixation through primary production, since higher rates were observed in surface waters of areas with major phy20 toplankton stocks. The diazotrophic community composition was mainly heterotrophic, which complement the idea of $\mathrm{N}_{2}$ fixation is related to DOM availability mainly release by phytoplankton and as a consequence related with community composition of phytoplankton (DOM quality). Therefore the regulation of $\mathrm{N}_{2}$ fixation by nutrient and $\mathrm{Fe}$ availability should be reconsidered, and further studies should include Fe availability as 25 well as phytoplankton and the diazotroph community composition. Finally, the spatial coverage of our study is limited, but considering that $\mathrm{N}_{2}$ fixation can occur in Fe limited areas as well as other Fe fertilized zones in the Southern Ocean, the significance of
BGD

$11,17151-17185,2014$

Nitrogen fixation in

the Southern Ocean

M. L. González et al.

Title Page

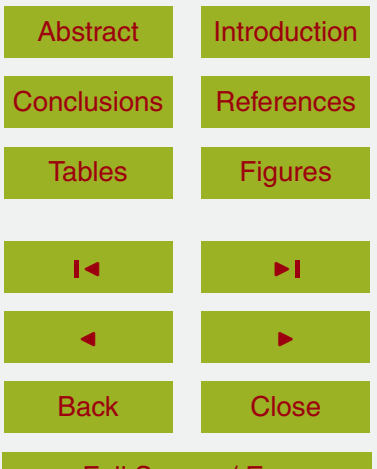

Full Screen / Esc

Printer-friendly Version

Interactive Discussion 
this process at the basin scale is underestimated by our data. This has implications for the assessment of the discordance between input and outputs of $\mathrm{N}$ to the global ocean.

Acknowledgements. The Captain and the crew of Marion Dufresne as well as KEOPS 2 5 Chief scientists B. Quéguiner and S. Blain are acknowledged for outstanding support during field work. Samples for molecular analysis were kindly provided by I. Obernosterer and S. Beier (LOMIC UMR 7621). This research was partially supported by Fondap INCAR project (15110027-CONICYT) and ECOS-CONICYT project C09B02. M. L. González was supported by COPAS SA program PFB-31 and CONICYT M.S. grant. This is a contribution to the LIA 10 MORFUN project (LIA 1025). F. Dehairs and A. J. Cavagna were supported by BELSPO, grant SD/CA/05A); Flanders Research Foundation (FWO; grant G071512N) and Vrije Universiteit Brussel (Strategic Research Plan).

\section{References}

Beier, S., Gálvez, M., Molina, V., Sarthou, G., Queroué, F., Blain, S., and Obernosterer, I.: The transcriptional regulation of the glyoxylate cycle in SAR11 in response to iron fertilization in the Southern Ocean, submitted, 2014.

Bergman, B. and Carpenter, E. J.: Nitrogenase confined to randomly distributed trichomes in the marine cyanobacterium Trichodesmiun thiebautii, J. Phycol., 27, 158-165, 1991.

Berman-Frank, I., Quigg, A., Finkel, Z. V., Irwin, A. J., and Haramaty, L.: Nitrogen-fixation strategies and Fe requirements in cyanobacteria, Limnol. Oceanogr., 52, 2260-2269, 2007.

Bird, C., Martinez, J. M., O'Donnell, A. G., and Wyman, M.: Spatial distribution and transcriptional activity of an uncultured clade of planktonic diazotrophic $\gamma$-Proteobacteria in the Arabian Sea, Appl. Environ. Microb., 71, 2079-2085, 2005.

Blain, S., Quéguiner, B., Armand, L., Belviso, S., Bombled, B., Bopp, L., Bowie, A., Brunet, C., Brussaard, C., and Carlotti, F.: Effect of natural iron fertilization on carbon sequestration in the Southern Ocean, Nature, 446, 1070-1074, 2007.

Blain, S., Bonnet, S., and Guieu, C.: Dissolved iron distribution in the tropical and sub tropical South Eastern Pacific, Biogeosciences, 5, 269-280, doi:10.5194/bg-5-269-2008, 2008a.
BGD

$11,17151-17185,2014$

Nitrogen fixation in

the Southern Ocean

M. L. González et al.

Title Page

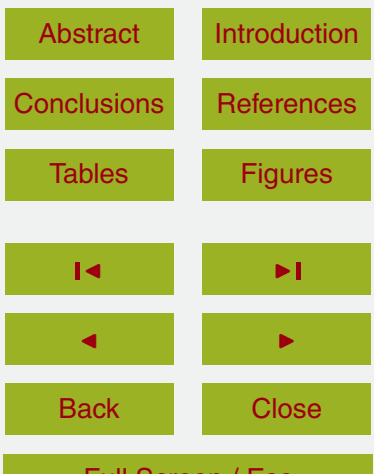

Full Screen / Esc

Printer-friendly Version

Interactive Discussion 
Blain, S., Sarthou, G. R., and Laan, P.: Distribution of dissolved iron during the natural ironfertilization experiment KEOPS (Kerguelen Plateau, Southern Ocean), Deep-Sea Res. Pt. II, 55, 594-605, 2008b.

Blain, S., Capparos, J., Guéneuguès, A., Obernosterer, I., and Oriol, L.: Distributions and stoichiometry of dissolved nitrogen and phosphorus in the iron fertilized region near Kerguelen (Southern Ocean), Biogeosciences Discuss., 11, 9949-9977, doi:10.5194/bgd-11-99492014, 2014.

Blais, M., Tremblay, J. Ã. R., Jungblut, A. D., Gagnon, J., Martin, J., Thaler, M., and Lovejoy, C.: Nitrogen fixation and identification of potential diazotrophs in the Canadian Arctic, Global Biogeochem. Cy., 26, GB3022, doi:10.1029/2011GB004096, 2012.

Bonnet, S., Biegala, I. C., Dutrieux, P., Slemons, L. O., and Capone, D. G.: Nitrogen fixation in the western equatorial Pacific: rates, diazotrophic cyanobacterial size class distribution, and biogeochemical significance, Global Biogeochem. Cy., 23, GB3012, doi:10.1029/2008GB003439, 2009.

Bonnet, S., Dekaezemacker, J., Turk-Kubo, K. A., Moutin, T., Hamersley, R. M., Grosso, O., Zehr, J. P., and Capone, D. G.: Aphotic $\mathrm{N}_{2}$ fixation in the Eastern Tropical South Pacific Ocean, PloS One, 8, e81265, doi:10.1371/journal.pone.0081265, 2013.

Capone, D. G., Burns, J. A., Montoya, J. P., Subramaniam, A., Mahaffey, C., Gunderson, T., Michaels, A. F., and Carpenter, E. J.: Nitrogen fixation by Trichodesmium spp.: an important source of new nitrogen to the tropical and subtropical North Atlantic Ocean, Global Biogeochem. Cy., 19, GB2024, doi:10.1029/2004GB002331, 2005.

Cavagna, A. J., Fripiat, F., Elskens, M., Dehairs, F., Mangion, P., Chirurgien, L., I.Closset, Lasbleiz, M., Flores-Leiva, L., Cardinal, D., Leblanc, K., Fernandez, C., Lefèvre, D., Oriol, L., and Quéguiner, B.: Biological productivity regime and associated $\mathrm{N}$ cycling in the surface waters over and downstream the Kerguelen Island area, Southern Ocean, Biogeosciences Discuss., submitted, 2014.

Chever, F., Sarthou, G., Bucciarelli, E., Blain, S., and Bowie, A. R.: An iron budget during the natural iron fertilisation experiment KEOPS (Kerguelen Islands, Southern Ocean), Biogeosciences, 7, 455-468, doi:10.5194/bg-7-455-2010, 2010.

30 Christaki, U., Lefèvre, D., Georges, C., Colombet, J., Catala, P., Courties, C., Sime-Ngando, T., Blain, S., and Obernosterer, I.: Microbial food web dynamics during spring phytoplankton blooms in the naturally iron-fertilized Kerguelen area (Southern Ocean), Biogeosciences Discuss., 11, 6985-7028, doi:10.5194/bgd-11-6985-2014, 2014.
BGD

11, 17151-17185, 2014

Nitrogen fixation in

the Southern Ocean

M. L. González et al.

Title Page

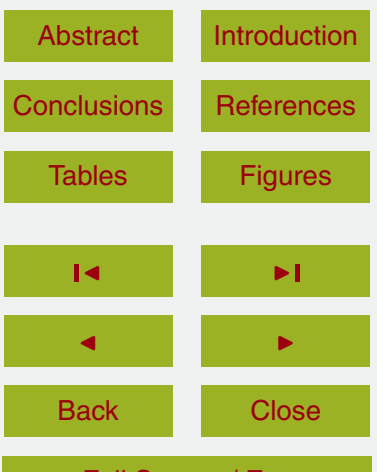

Full Screen / Esc

Printer-friendly Version

Interactive Discussion 
Church, M. J., Jenkins, B. D., Karl, D. M., and Zehr, J. P.: Vertical distributions of nitrogen-fixing phylotypes at Stn ALOHA in the oligotrophic North Pacific Ocean, Aquat. Microb. Ecol., 38, 3-14, 2005.

Codispoti, L. A.: Is the ocean losing nitrate?, Nature, 376, p. 724, 1995.

5 Dalsgaard, T., Canfield, D. E., Petersen, J., Thamdrup, B., and González, J.: N ${ }_{2}$ production by the anammox reaction in the anoxic water column of Golfo Dulce, Costa Rica, Nature, 422, 606-608, 2003.

Dehairs, F., Fripiat, F., Cavagna, A.-J., Trull, T. W., Fernandez, C., Davies, D., Roukaerts, A., Fonseca Batista, D., Planchon, F., and Elskens, M.: Nitrogen cycling in the Southern Ocean Kerguelen Plateau area: evidence for significant surface nitrification from nitrate isotopic compositions, Biogeosciences Discuss., 11, 13905-13955, doi:10.5194/bgd-11-139052014, 2014.

Dekaezemacker, J., Bonnet, S., Grosso, O., Moutin, T., Bressac, M., and Capone, D. G.: Evidence of active dinitrogen fixation in surface waters of the eastern tropical South Pacific during El Niño and La Niña events and evaluation of its potential nutrient controls, Global Biogeochem. Cy., 27, 768-779, doi:10.1002/gbc.20063, 2013.

Edgar, R. C.: MUSCLE: multiple sequence alignment with high accuracy and high throughput, Nucleic Acids Res., 32, 1792-1797, 2004.

Falcón, L. I., Carpenter, E. J., Cipriano, F., Bergman, B., and Capone, D. G.: $\mathrm{N}_{2}$ fixation by unicellular bacterioplankton from the Atlantic and Pacific Oceans: phylogeny and in situ rates, Appl. Environ. Microb., 70, 765-770, 2004.

Falkowski, P. G.: Evolution of the nitrogen cycle and its influence on the biological sequestration of $\mathrm{CO}_{2}$ in the ocean, Nature, 387, 272-275, 1997.

Farnelid, H., Tarangkoon, W., Hansen, G., Hansen, P. J., and Riemann, L.: Putative $\mathrm{N}_{2}$-fixing heterotrophic bacteria associated with dinoflagellate-Cyanobacteria consortia in the lownitrogen Indian Ocean, Aquat. Microb. Ecol., 61, 105-117, 2010.

Fernandez, C., Farias, L., and Ulloa, O.: Nitrogen fixation in denitrified marine waters, PloS One, 6, e20539, doi:10.1371/journal.pone.0020539, 2011.

Fourquez, M., Obernosterer, I., Davies, D. M., Trull, T. W., and Blain, S.: Microbial iron uptake in the naturally fertilized waters in the vicinity of Kerguelen Islands: phytoplankton-bacteria interactions, Biogeosciences Discuss., 11, 15053-15086, doi:10.5194/bgd-11-15053-2014, 2014. 
Goeyens, L., Semeneh, M., Baumann, M. E. M., Elskens, M., Shopova, D., and Dehairs, F.: Phytoplanktonic nutrient utilisation and nutrient signature in the Southern Ocean, J. Marine Syst., 17, 143-157, 1998.

Gruber, N. and Sarmiento, J. L.: Global patterns of marine nitrogen fixation and denitrification, Global Biogeochem. Cy., 11, 235-266, 1997.

Halm, H., Lam, P., Ferdelman, T. G., Lavik, G., Dittmar, T., LaRoche, J., D'Hondt, S., and Kuypers, M. M. M.: Heterotrophic organisms dominate nitrogen fixation in the South Pacific Gyre, ISME J., 6, 1238-1249, 2012.

Karl, D., Michaels, A., Bergman, B., Capone, D., Carpenter, E., Letelier, R., Lipschultz, F., Paerl, H., Sigman, D., and Stal, L.: Dinitrogen Fixation in the World's Oceans, Springer, 2002.

Kustka, A., Carpenter, E. J., and Sañudo-Wilhelmy, S. A.: Iron and marine nitrogen fixation: progress and future directions, Res. Microbiol., 153, 255-262, 2002.

Kustka, A., Sañudo-Wilhelmy, S., Carpenter, E. J., Capone, D. G., and Raven, J. A.: A revised estimate of the iron use efficiency of nitrogen fixation, with special referenceto the marine cyanobacterium Trichodesmium spp. (Cyanophyta), J. Phycol., 39, 12-25, 2003.

LaRoche, J. and Breitbarth, E.: Importance of the diazotrophs as a source of new nitrogen in the ocean, J. Sea Res., 53, 67-91, 2005.

Lasbleiz, M., Leblanc, K., Blain, S., Ras, J., Cornet-Barthaux, V., Hélias Nunige, S., and Quéguiner, B.: Pigments, elemental composition ( $\mathrm{C}, \mathrm{N}, \mathrm{P}$, and $\mathrm{Si})$, and stoichiometry of particulate matter in the naturally iron fertilized region of Kerguelen in the Southern Ocean, Biogeosciences, 11, 5931-5955, doi:10.5194/bg-11-5931-2014, 2014.

Loescher, C. R., Groskopf, T., Desai, F. D., Gill, D., Schunck, H., Croot, P. L., Schlosser, C., Neulinger, S. C., Pinnow, N., Lavik, G., Kuypers, M. M. M., LaRoche, J., and Schmitz, R. A.: Facets of diazotrophy in the oxygen minimum zone waters off Peru, ISME J., 8, 2180-2192, 2014.

Luo, Y.-W., Lima, I. D., Karl, D. M., Deutsch, C. A., and Doney, S. C.: Data-based assessment of environmental controls on global marine nitrogen fixation, 2014.

Man-Aharonovich, D., Kress, N., Zeev, E. B., Berman-Frank, I., and Béja, O.: Molecular ecology 30 of nifH genes and transcripts in the eastern Mediterranean Sea, Environ. Microbiol., 9, 23542363, 2007.

Marie, D., Simon, N., Guillou, L., Partensky, F., and Vaulot, D.: Flow cytometry analysis of marine picoplankton, in: In Living Color, Springer, 421-454, 2000.

Nitrogen fixation in

the Southern Ocean

M. L. González et al.

Title Page

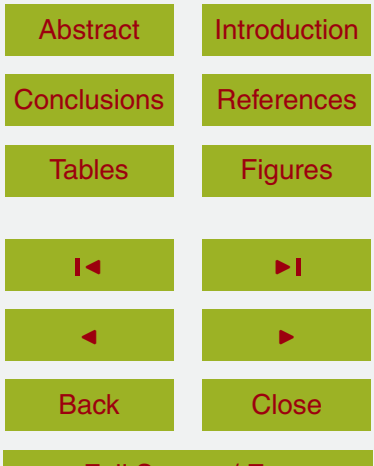

Full Screen / Esc

Printer-friendly Version

Interactive Discussion

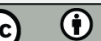


Mehta, M. P. and Baross, J. A.: Nitrogen fixation at $92^{\circ} \mathrm{C}$ by a hydrothermal vent archaeon, Science, 314, 1783-1786, 2006.

Mehta, M. P., Butterfield, D. A., and Baross, J. A.: Phylogenetic diversity of nitrogenase (nifH) genes in deep-sea and hydrothermal vent environments of the Juan de Fuca Ridge, Appl.

$5 \quad$ Environ. Microb., 69, 960-970, 2003.

Michaels, A. F., Olson, D., Sarmiento, J. L., Ammerman, J. W., Fanning, K., Jahnke, R., Knap, A. H., Lipschultz, F., and Prospero, J. M.: Inputs, losses and transformations of nitrogen and phosphorus in the pelagic North Atlantic Ocean, in: Nitrogen Cycling in the North Atlantic Ocean and Its Watersheds, Springer, 181-226, 1996.

10 Mills, M. M., Ridame, C., Davey, M., La Roche, J., and Geider, R. J.: Iron and phosphorus co-limit nitrogen fixation in the eastern tropical North Atlantic, Nature, 429, 292-294, 2004.

Moisander, P. H., Shiue, L., Steward, G. F., Jenkins, B. D., Bebout, B. M., and Zehr, J. P.: Application of a nifH oligonucleotide microarray for profiling diversity of $\mathrm{N}_{2}$-fixing microorganisms in marine microbial mats, Environ. Microbiol., 8, 1721-1735, 2006.

Moisander, P. H., Beinart, R. A., Voss, M., and Zehr, J. P.: Diversity and abundance of diazotrophic microorganisms in the South China Sea during intermonsoon, ISME J., 2, 954967, 2008.

Montoya, J. P., Voss, M., Kahler, P., and Capone, D. G.: A Simple, High-Precision, HighSensitivity Tracer Assay for N (inf2) Fixation, Appl. Environ. Microb., 62, 986-993, 1996.

20 Montoya, J. P., Holl, C. M., Zehr, J. P., Hansen, A., Villareal, T. A., and Capone, D. G.: High rates of $\mathrm{N}_{2}$ fixation by unicellular diazotrophs in the oligotrophic Pacific Ocean, Nature, 430, 1027-1032, 2004.

Needoba, J. A., Foster, R. A., Sakamoto, C., Zehr, J. P., and Johnson, K. S.: Nitrogen fixation by unicellular diazotrophic cyanobacteria in the temperate oligotrophic North Pacific Ocean,

25 Limnol. Oceanogr., 52, 1317-1327, 2007.

Park, Y.-H., Durand, I., Kestenare, E., Rougier, G., Zhou, M., d'Ovidio, F., Cotté, C., and Lee, J.$\mathrm{H}$.: Polar Front around the Kerguelen Islands: an up-to-date determination and associated circulation of surface/subsurface waters, J. Geophys. Res.-Oceans, 119, 6575-6592, 2014.

Pollard, R., Sanders, R., Lucas, M., and Statham, P.: The Crozet natural iron bloom and export experiment (CROZEX), Deep-Sea Res. Pt. II, 54, 1905-1914, 2007.

Price, M. N., Dehal, P. S., and Arkin, A. P.: FastTree an approximately maximum-likelihood trees for large alignments, PloS One, 5, e9490, doi:10.1371/journal.pone.0009490, 2010. 
Quéroué, F., Sarthou, G., Planquette, H. F., Bucciarelli, E., Chever, F., Merwe, P. v. d., Lannuzel, D., Townsend, A. T., Cheize, M., Blain, S., d'Ovidio, F., and Bowie, A. R.: High variability of dissolved iron concentrations in the vicinity of Kerguelen Island (Southern Ocean), Biogeosciences Discuss., submitted, 2014.

5 Ramirez-Flandes, S. and Ulloa, O.: Bosque: integrated phylogenetic analysis software, Bioinformatics, 24, 2539-2541, 2008.

Raven, J. A.: The iron and molybdenum use efficiencies of plant growth with different energy, carbon and nitrogen sources, New Phytol., 109, 279-287, 1988.

Riemann, L., Steward, G. F., and Azam, F.: Dynamics of bacterial community composition and activity during a mesocosm diatom bloom, Appl. Environ. Microb., 66, 578-587, 2000.

Riemann, L., Farnelid, H., and Steward, G. F.: Nitrogenase genes in non-cyanobacterial plankton: prevalence, diversity and regulation in marine waters, Aquat. Microb. Ecol., 61, 235-247, 2010.

Short, S. M., Jenkins, B. D., and Zehr, J. P.: Spatial and temporal distribution of two diazotrophic bacteria in the Chesapeake Bay, Appl. Environ. Microb., 70, 2186-2192, 2004.

Sohm, J. A., Webb, E. A., and Capone, D. G.: Emerging patterns of marine nitrogen fixation, Nat. Rev. Micro., 9, 499-508, 2011.

Tripp, H. J., Bench, S. R., Turk, K. A., Foster, R. A., Desany, B. A., Niazi, F., Affourtit, J. P., and Zehr, J. P.: Metabolic streamlining in an open-ocean nitrogen-fixing cyanobacterium, Nature, 464, 90-94, 2010.

Turk-Kubo, K. A., Karamchandani, M., Capone, D. G., and Zehr, J. P.: The paradox of marine heterotrophic nitrogen fixation: abundances of heterotrophic diazotrophs do not account for nitrogen fixation rates in the Eastern Tropical South Pacific, Environ. Microbiol., 16, doi:10.1111/1462-2920.12346, 2013.

Vaulot, D., Courties, C., and Partensky, F.: A simple method to preserve oceanic phytoplankton for flow cytometric analyses, Cytometry, 10, 629-635, 1989.

Voss, M., Croot, P., Lochte, K., Mills, M., and Peeken, I.: Patterns of nitrogen fixation along 10 $\mathrm{N}$ in the tropical Atlantic, Geophys. Res. Lett., 31, doi:10.1029/2004GL020127, 2004.

Yogev, T., Rahav, E., Bar-Zeev, E., Man-Aharonovich, D., Stambler, N., Kress, N., Béjà, O., 30 Mulholland, M. R., Herut, B., and Berman-Frank, I.: Is dinitrogen fixation significant in the Levantine Basin, East Mediterranean Sea?, Environ. Microbiol., 13, 854-871, 2011.

Zahn, R., Pedersen, T., Kaminski, M., Labeyrie, L., and Montoya, J.: Nitrogen isotope fractionation in the modern ocean: implications for the sedimentary record, in: Carbon Cycling in
BGD

11, 17151-17185, 2014

Nitrogen fixation in

the Southern Ocean

M. L. González et al.

Title Page

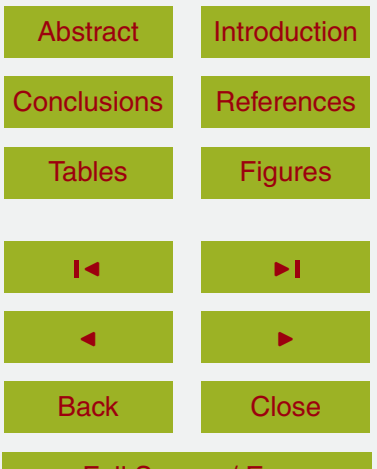

Full Screen / Esc

Printer-friendly Version

Interactive Discussion 
the Glacial Ocean: Constraints on the Oceans Role in Global Change, NATO ASI Series, Springer, Berlin, Heidelberg, 259-279, 1994.

Zehr, J. P., Mellon, M. T., and Zani, S.: New nitrogen-fixing microorganisms detected in oligotrophic oceans by amplification of nitrogenase (nifH) genes, Appl. Environ. Microb., 64, 5 3444-3450, 1998.

Zehr, J. P., Waterbury, J. B., Turner, P. J., Montoya, J. P., Omoregie, E., Steward, G. F., Hansen, A., and Karl, D. M.: Unicellular cyanobacteria fix $\mathrm{N}_{2}$ in the subtropical North Pacific Ocean, Nature, 412, 635-638, 2001.

Zehr, J. P., Jenkins, B. D., Short, S. M., and Steward, G. F.: Nitrogenase gene diversity and microbial community structure: a cross-system comparison, Environ. Microbiol., 5, 539-554, 2003.

Zehr, J. P., Bench, S. R., Carter, B. J., Hewson, I., Niazi, F., Shi, T., Tripp, H. J., and Affourtit, J. P.: Globally distributed uncultivated oceanic $\mathrm{N}_{2}$-fixing cyanobacteria lack oxygenic photosystem II, Science, 322, 1110-1112, 2008.

Zehr, J. P. and Kudela, R. M.: Nitrogen cycle of the open ocean: from genes to ecosystems, Annual Review of Marine Science, 3, 197-225, 2011.

Zhou, M., Zhu, Y., d'Ovidio, F., Park, Y.-H., Durand, I., Kestenare, E., Sanial, V., Van-Beek, P., Queguiner, B., Carlotti, F., and Blain, S.: Surface currents and upwelling in Kerguelen Plateau regions, Biogeosciences Discuss., 11, 6845-6876, doi:10.5194/bgd-11-6845-2014, 2014.

Nitrogen fixation in the Southern Ocean

M. L. González et al.

Title Page

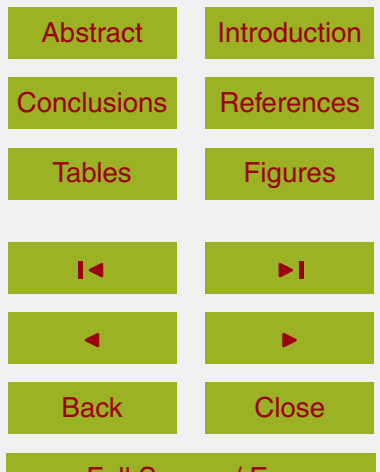

Full Screen / Esc

Printer-friendly Version

Interactive Discussion 
Table 1. Sampling stations visited during the KEOPS2 cruise and rates of $\mathrm{N}_{2}$ fixation, ammonium and nitrate assimilation obtained.

\begin{tabular}{llllllll}
\hline Station & $\begin{array}{l}\text { Latitude } \\
\left({ }^{\circ} \mathrm{S}\right)\end{array}$ & $\begin{array}{l}\text { Longitude } \\
\left({ }^{\circ} \mathrm{E}\right)\end{array}$ & $\begin{array}{l}\mathrm{MLD} \\
(\mathrm{m})\end{array}$ & $\begin{array}{l}\mathrm{PZ} \\
(\mathrm{m})\end{array}$ & $\begin{array}{l}\mathrm{N}_{2} \text { fixation rate } \\
\left(\mathrm{nmol} \mathrm{L}^{-1} \mathrm{~d}^{-1}\right)\end{array}$ & $\begin{array}{l}\rho \mathrm{NH}_{4}^{+} \\
\left(\mu \mathrm{mol} \mathrm{L}^{-1} \mathrm{~d}^{-1}\right)^{*}\end{array}$ & $\begin{array}{l}\rho \mathrm{NO}_{3}^{-} \\
\left(\mu \mathrm{mol} \mathrm{L}^{-1} \mathrm{~d}^{-1}\right)^{*}\end{array}$ \\
\hline $\mathrm{R}-2$ & 50.3834 & 66.6835 & 123 & 92 & $4.45 \pm 2.6$ & $0.44 \pm 0.01$ & $0.029 \pm 0.01$ \\
$\mathrm{~A} 3-2$ & 50.6168 & 72.0501 & 123 & 38 & $3.27 \pm 2.8$ & $0.6 \pm 0.02$ & $0.55 \pm 0.36$ \\
$\mathrm{E}-4 \mathrm{~W}$ & 48.7503 & 71.4168 & 64 & 31 & $5.41 \pm 2.2$ & $0.004 \pm 0.001$ & $0.8 \pm 0.53$ \\
$\mathrm{~F}-\mathrm{L}$ & 48.5169 & 74.6501 & 47 & 29 & $10.27 \pm 7.5$ & $0.33 \pm 0.3$ & $1.9 \pm 1.4$ \\
$\mathrm{E}-1$ & 48.4501 & 72.1834 & 133 & 64 & $3.48 \pm 2.8$ & $0.041 \pm 0.02$ & $0.11 \pm 0.08$ \\
$\mathrm{E}-3$ & 48.7000 & 71.9667 & 40 & 68 & $2.59 \pm 0.5$ & $0.076 \pm 0.04$ & $0.153 \pm 0.03$ \\
$\mathrm{E}-4 \mathrm{E}$ & 48.7003 & 72.5502 & 80 & 48 & $2.82 \pm 1.2$ & $0.10 \pm 0.03$ & $0.26 \pm 0.17$ \\
$\mathrm{E}-5$ & 48.4002 & 71.8836 & 38 & 54 & $4.82 \pm 1.1$ & $0.08 \pm 0.04$ & $0.18 \pm 0.14$ \\
\hline
\end{tabular}

${ }^{*}$ Data reported in Cavagna et al. (2014).

Nitrogen fixation in the Southern Ocean

M. L. González et al.

Title Page

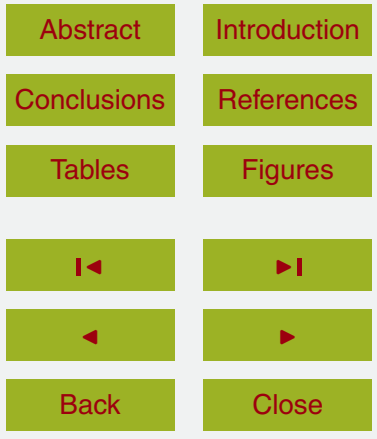

Full Screen / Esc

Printer-friendly Version

Interactive Discussion 
Table 2. Comparative table of areal $\mathrm{N}_{2}$ fixation rates of different regions of the global ocean. HNLC (high Nutrient Low Chlorophyll), ETSP (Easter Tropical South Pacific), SPG (South Pacific Gyre), WEP (Western Equatorial Pacific), NPO (North Pacific Ocean), TNA (Tropical North Atlantic) and STNA (SubTropical North Atlantic).

\begin{tabular}{lll}
\hline $\begin{array}{l}\mathrm{N}_{2} \text { fixation rate } \\
\left(\mu \mathrm{mol} \mathrm{m} \mathrm{m}^{-2} \mathrm{~d}^{-1}\right)\end{array}$ & Region & Source \\
\hline $4-53$ & HNLC zone ETSP & (Dekaezemacker et al., 2013) \\
94 & SPG & (Halm et al., 2012) \\
6.5 & Arctic Zone & (Blais et al., 2012) \\
48 & HNLC zone ETSP & (Fernandez et al., 2011) \\
2.6 & Mediterranean Sea & (Yogev et al., 2011) \\
18 & HNLC zone WEP & (Bonnet et al., 2009) \\
10 & Oligotrophic NPO & (Needoba et al., 2007) \\
$37-47$ & TNA & (Falcón et al., 2004) \\
4 & STNA & \\
\hline
\end{tabular}

Nitrogen fixation in the Southern Ocean

M. L. González et al.

Title Page

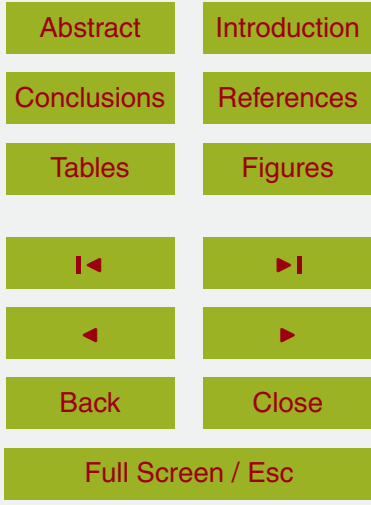

Printer-friendly Version

Interactive Discussion 


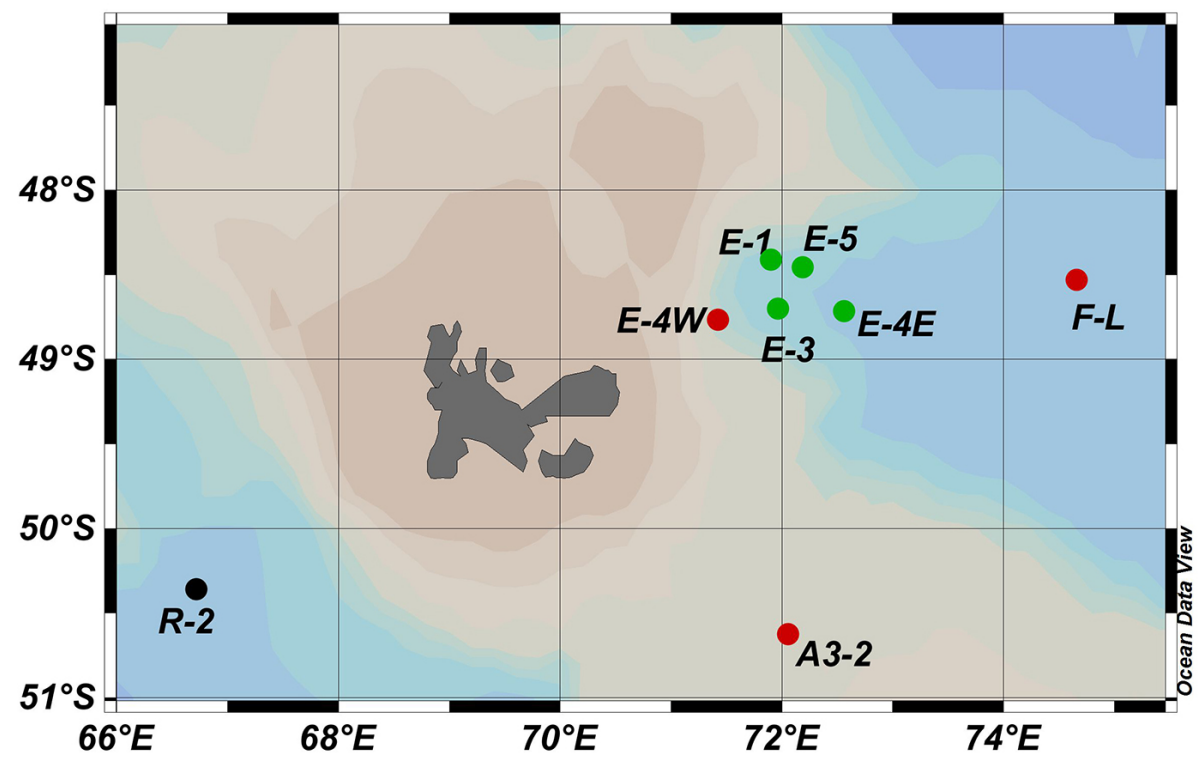

Figure 1. Location of sampling stations in Kerguelen Island. Black dots represent the location of R-2 station (HNLC area). Red dots are location of the processes stations A3-2, E-4W and FL. Green dots represent the location of "E" stations with a Lagrangian framework.

\section{BGD}

$11,17151-17185,2014$

Nitrogen fixation in the Southern Ocean

M. L. González et al.

Title Page

Abstract

Introduction

Conclusions

References

Tables

Figures

14

$>$ I

4

Back

Close

\section{Full Screen / Esc}

Printer-friendly Version

Interactive Discussion 



d)



Figure 2. Sectional distribution of density and $\mathrm{N}^{*}$ for both transects. (a) Density $\left(\mathrm{kg} \mathrm{m}^{-3}\right)$ and (b) $\mathrm{N}^{*}$ for the north to south transect (TNS), (c) density $\left(\mathrm{kg} \mathrm{m}^{-3}\right)$ and (d) $\mathrm{N}^{*}$ for the west to east transect (TWE).

\section{BGD}

11, 17151-17185, 2014

Nitrogen fixation in the Southern Ocean

M. L. González et al.

Title Page

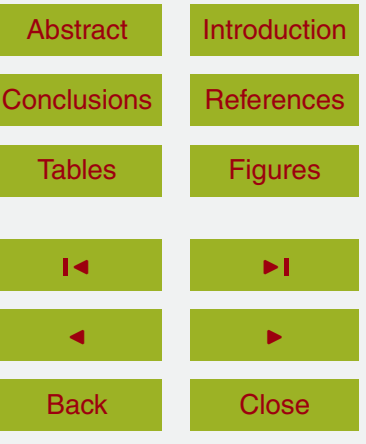

Full Screen / Esc

Printer-friendly Version

Interactive Discussion 



d) ${ }^{70}$

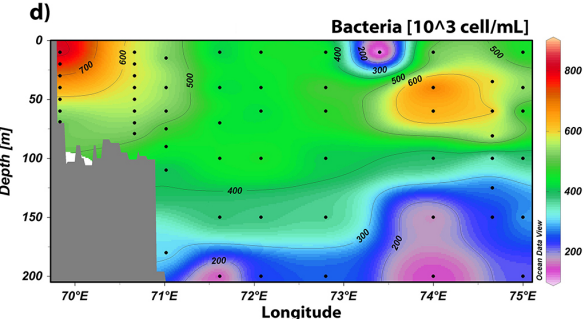

Figure 3. Sectional distribution of density $\left(\mathrm{kg} \mathrm{m}^{-3}\right), \mathrm{N}^{*}$, fluorescence $\left(\mu \mathrm{gL}^{-1}\right)$ and bacterial abundance $\left(10^{3}\right.$ cells $\left.\mathrm{mL}^{-1}\right)$ for "E" stations. (a) Density, (b) $\mathrm{N}^{*}$, (c) fluorescence, and (d) bacterial abundance.

\section{BGD}

11, 17151-17185, 2014

Nitrogen fixation in the Southern Ocean

M. L. González et al.

Title Page

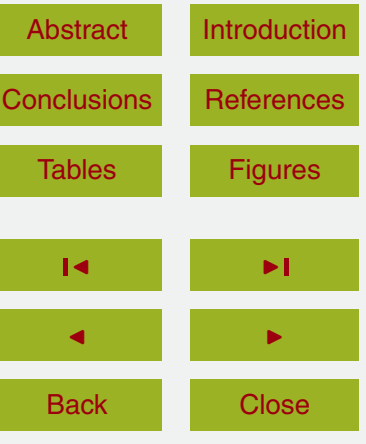

Full Screen / Esc

Printer-friendly Version

Interactive Discussion 

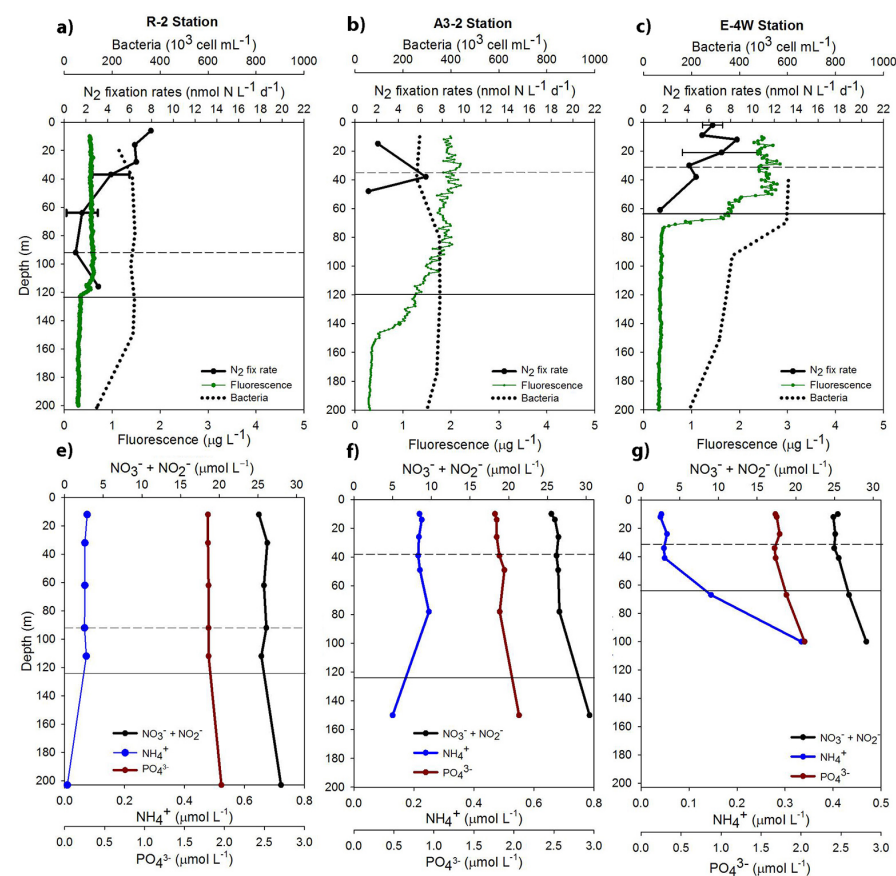

g)
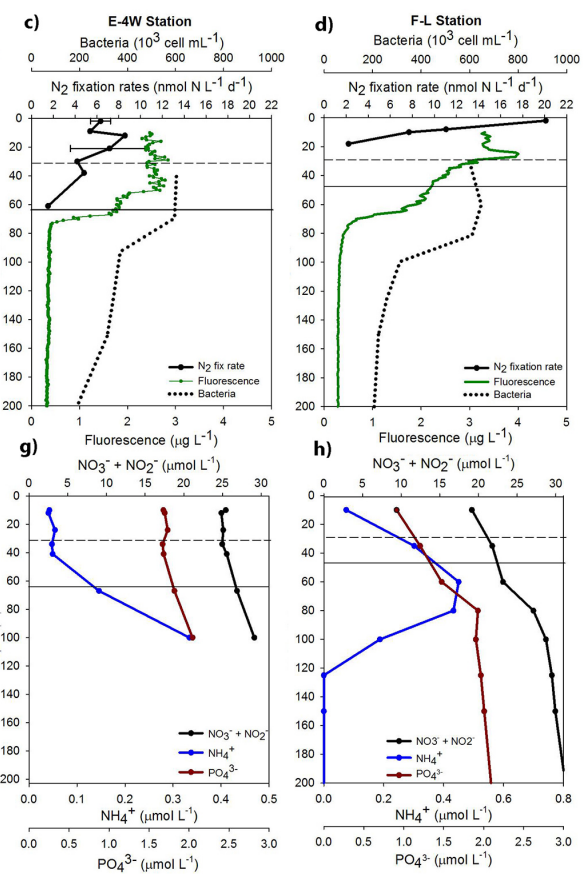

Figure 4. $\mathrm{N}_{2}$ fixation rates $\left(\mathrm{nmolNL} \mathrm{N}^{-1} \mathrm{~d}^{-1}\right)$, fluorescence $\left(\mu \mathrm{L}^{-1}\right)$, bacterial abundance $\left(10^{3}\right.$ cells $\left.\mathrm{mL}^{-1}\right)$, and nutrients profiles for reference and processes stations. $\mathrm{R}$ station (a and e), A3-2 (b and f), E-4W (c and $\mathbf{g}$ ) and F-L ( $\mathbf{d}$ and $\mathbf{h}$ ). the dashed line represent the Photic Layer (1\% incident ligth) and solid line represents the Mix Layer Depth (MLD).

\section{BGD}

$11,17151-17185,2014$

Nitrogen fixation in the Southern Ocean

M. L. González et al.

Title Page

Abstract

Introduction

Conclusions

References

Tables

Figures

$1<$

$>$

4

Back

Close

\section{Full Screen / Esc}

Printer-friendly Version

Interactive Discussion 




BGD

11, 17151-17185, 2014

Nitrogen fixation in the Southern Ocean

M. L. González et al.

Title Page

Abstract

Introduction

Conclusions

References

Tables

Figures

14

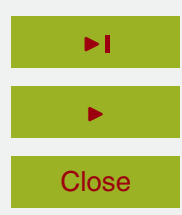

Back

Close

\section{Full Screen / Esc}

Printer-friendly Version

Interactive Discussion

Figure 5. Time evolution of $\mathrm{N}_{2}$ fixation rates (a) and $\delta^{15} \mathrm{~N}$ from Particulate Organic Material (POM) (b) at "E" stations. 

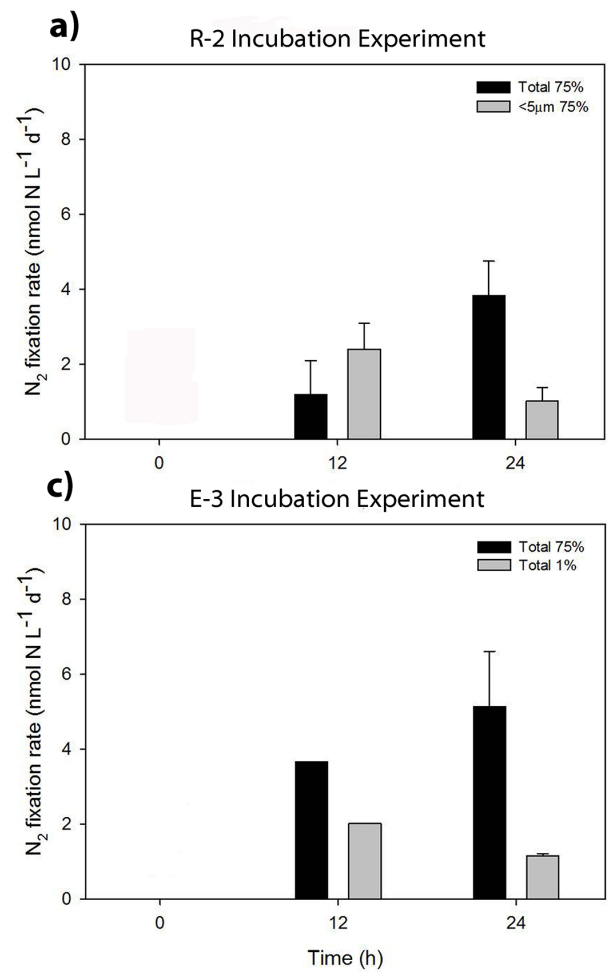

b)

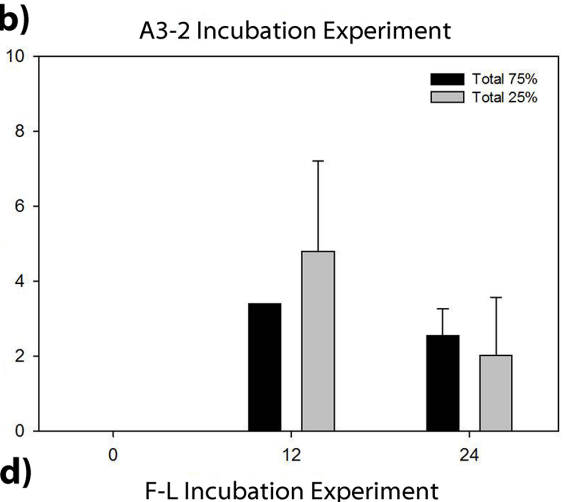

d)

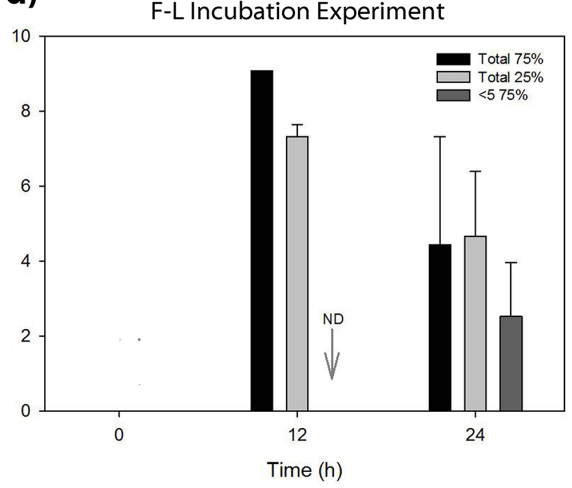

Figure 6. $\mathrm{N}_{2}$ fixation rates at Incubation experiments at $\mathrm{R}$ station (a), A3-2 station (b), E-3 station (c) and F-L station (d), with different incident light (75, 25 and 1\%) for the total community and $<5 \mu \mathrm{m}$ size fraction. ND = No data.

\section{BGD}

11, 17151-17185, 2014

Nitrogen fixation in the Southern Ocean

M. L. González et al.

Title Page

Abstract

Introduction

Conclusions

References

Tables

Figures

14

$>$

4

Back

Close

\section{Full Screen / Esc}

Printer-friendly Version

Interactive Discussion 


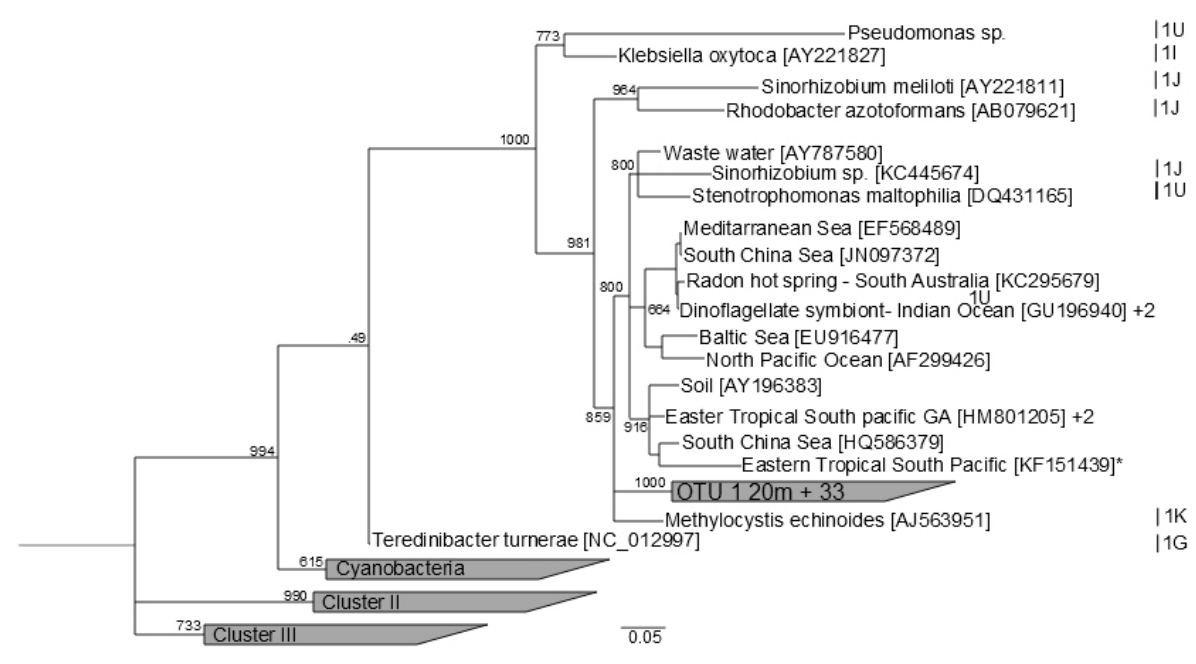

Figure 7. Phylogenetic tree including 34 nucleotide nifH sequences obtained from the study site (E-1 station, $20 \mathrm{~m}$ ), the sequences are represented in one OUT and sequences form uncultured and cultures diazotrophic groups. The values represent the number of boostrap in base of 1000 replicates from mayor cluster to subclusters. The subcluster indicated at right side of the tree it was obtained from previous reports (Zehr et al., 2003; Turk-Kubo et al., 2013).

\section{BGD}

$11,17151-17185,2014$

Nitrogen fixation in the Southern Ocean

M. L. González et al.

Title Page

Abstract

Introduction

Conclusions

References

Tables

Figures

$1<$

$>1$

4

Back

Close

Full Screen / Esc

Printer-friendly Version

Interactive Discussion 